Elsevier Editorial System(tm) for

nd Society

Manuscript Draft

Manuscript Number: AOS-D-15-00178R4

Title: Performative Agency and Incremental Change in a CSR Context

Article Type: Research paper

Corresponding Author: Dr. Claudine Grisard, PhD

Corresponding Author's Institution: Strathclyde School of Business

First Author: Claudine Grisard, PhD

Order of Authors: Claudine Grisard, PhD; Marcia Annisette, PhD; Cameron Graham, PhD

Abstract: Based on a two-year participant observation, this paper shows how CSR managers align CSR programs closer to their personal convictions and eventually bring about incremental change. We focus on two CSR managers working on a project to develop a business aimed at serving rural West African consumers and show that while they frame their project in financial terms, they incrementally transform the firm's representations in accordance with their own vision of CSR. We deploy Butler's understanding of subjection through performative agency to show that even if CSR managers reproduce the CSR business case discourse to render their actions legitimate and recognizable, this empowers them to exercise a small degree of agency, allowing them to infuse a more inclusive perception of rural low-income populations into the firm's practices. This paper makes two contributions. First, it shows that the subject can incrementally act to transform the dominant financial discourse governing her subjection to better align it with her own desire. Second, we establish that the CSR manager navigates between the traditional duo of CSR actors: the organization and its stakeholders and therefore renders porous the boundary between them both. 


\section{Performative Agency and Incremental Change in a CSR Context}

\section{Claudine Grisard*}

Strathclyde Business School, University of Strathclyde, Glasgow

\section{Marcia Annisette and Cameron Graham}

Schulich School of Business, York University, Toronto

* Corresponding author:

Claudine Grisard

Room SW322, Strathclyde Business School

Livingstone Tower, 16 Richmond St, Glasgow G1 1XH

United-Kingdom

E-mail: claudine.grisard@strath.ac.uk

Acknowledgements: Funding for this research was provided by L'Ordre des Experts Comptables. The authors gratefully acknowledge the constructive comments of David Cooper, Martin Messner, Nicolas Berland, Christine Cooper, Claire-France Picard, Rebekah Willson, Jeff Everett and colleagues at the Schulich School of Business, Crawford Spence, Rita Samiolo, and colleagues at the King's Business School. 


\title{
Performative Agency and Incremental Change in a CSR Context
}

\begin{abstract}
Based on a two-year participant observation, this paper shows how CSR managers align CSR programs closer to their personal convictions and eventually bring about incremental change. We focus on two CSR managers working on a project to develop a business aimed at serving rural West African consumers and show that while they frame their project in financial terms, they incrementally transform the firm's representations in accordance with their own vision of CSR. We deploy Butler's understanding of subjection through performative agency to show that even if CSR managers reproduce the CSR business case discourse to render their actions legitimate and recognizable, this empowers them to exercise a small degree of agency, allowing them to infuse a more inclusive perception of rural low-income populations into the firm's practices. This paper makes two contributions. First, it shows that the subject can incrementally act to transform the dominant financial discourse governing her subjection to better align it with her desire. Second, we establish that the CSR manager navigates between the traditional duo of CSR actors: the organization and its stakeholders and therefore renders porous the boundary between them both.
\end{abstract}

Key words: incremental changes, performative agency, CSR, subjection. 


\section{Introduction}

I, I started to develop an interest in malaria by accident. And indeed, it is an illness, which me... I hadn't realized how tragic it was, regarding impacts for local populations and local eco-systems. So, we tried to see what we could do with malaria. We developed a medicine which follows WHO's guidelines. It is a medicine, which is the easiest to imagine since it is one tablet per day. We sell it at cost price. (CSR Manager at Pharmaceutical Corporation, August 2010) ${ }^{1}$

In the above quote, a CSR manager working for a major pharmaceutical firm in France is discussing a drug program designed to treat African populations affected by malaria. While describing the program, the employee suddenly becomes emotional when explaining how a closer understanding of the illness and its impacts on populations changed his approach to the issue. His experience, so he suggests, has made him more sensitive to and passionate about the cause. The quote reveals the image of a CSR manager ostensibly driven by humanitarian rather than profit motives with regards to his organization's involvement in the fight against malaria - an image at variance with the managerialist literature in which 'being good' for businesses is the primary rationale for investment in CSR projects. Indeed, many CSR projects have been conceived and justified within a framework which insists that any actions aimed at satisfying a firm's wider group of stakeholders must contribute to the long-term maximization of shareholder value (Jensen 2002). For example, Porter and Kramer (2011) posit that CSR projects can help firms win the loyalty of existing consumers, attract new customers and eventually maintain growth by creating new products with components that benefit the environment and society. Prahalad and Hammond (2002) hold a similar view in suggesting that the development of products and services aimed at people living on $\$ 2$ a day whilst helping to alleviate poverty also creates new sources of profit and growth for the organization. These latter arguments lie at the root of the well-established business case for CSR.

The accounting literature has given a detailed account of the drawbacks of this managerialist approach to CSR - otherwise referred to as the CSR business case discourse. Authors have critically reviewed firms' CSR activities and reports thereof and question both the real benefit of those activities to stakeholder groups and the ethical and moral potential of the associated discourse (Neu et al. 1998; Cho et al. 2010; Gray 1992; Cho et al. 2012; Sikka 2011; Adams and Whelan 2009; Adams

\footnotetext{
${ }^{1}$ Verbatim quotes extracted from a set of interviews conducted in the exploratory phase preceding the collection of the data used in this paper. 19 interviews were conducted in 14 of the 15 French multinational corporations identified as having developed for-profit business projects aimed at reducing poverty.
} 
2004; O'Dwyer 2002; Archel et al. 2011; Gray 2010; Malsch 2013; Milne et al. 2009; O'Dwyer 2003; O'Dwyer et al. 2011; Spence 2007, 2009; Spence et al. 2010). In particular, the CSR business case discourse and the practices that inform it have been described as being for the most part an 'appearance of ethics' designed to protect the interests of shareholders and is therefore devoid of genuine empathy for and impact on those who suffer (Baker and Roberts 2011; Roberts 2003). Thus, the CSR business case discourse is typically seen as an extension of the more general business discourse aimed at serving the interests of shareholders. However, in the quote given above, the CSR manager seems to have been moved by his experience and deeply empathizes with the suffering of others, thereby implying a disjuncture between the depiction of CSR practice in the accounting critique and CSR as a lived practice for CSR managers. This paper is therefore concerned with the way that CSR managers such as the one above deal with their personal convictions in the context of a pervasive managerialist attitude towards CSR programs.

In the paper, we conceptualize the CSR business case as a discourse of power governing the construction of the disciplined CSR manager. Because this discourse is underpinned by accounting metrics and vocabularies, our approach to interrogating the nexus between CSR and accounting is based on a micro-analytical perspective - that is, we focus our attention on individual actors. This stands in contrast to the extant accounting literature on CSR which tends to adopt a macro-analytic approach focused primarily on social and environmental reports ${ }^{2}$, with authors discussing its democratic promise (Unerman and Bennett 2004) and dialogic potential (Brown 2009; Brown and Dillard 2013a) or denouncing it as a hegemonic discourse of the business case (Spence 2007). We also stand in contrast to much of the extant Foucauldian literature in accounting in that whilst we do accept the premise that as a numerical technology, accounting helps transform individuals into "governable subjects" (Miller and O'Leary 1987), our focus is less about the disciplinary effects of accounting and more about the manner in which individuals perform the discourse and the consequences of such performance. By conducting a microanalysis of CSR managers, we investigate the interplay between their convictions and desires and the CSR business case discourse and explore their potential to influence CSR practices. Thus, whilst we recognize the disciplinary effects of managerial discourses of power, we wish to explore the capacity of individuals, even as they are

\footnotetext{
2 In this literature, we also include the emerging management accounting literature, which aims to understand how management accounting systems work to collect CSR information and infuse CSR within organizational practices so as to construct a more robust CSR report (Arjaliès and Mundy 2013; Bebbington and Thomson 2013; Contrafatto and Burns 2013).
} 
disciplined, to bring about change. In so doing, we rely on the notion of performative agency developed by Butler (1990, 1993, 1997a, 1997b, 2004, 2005).

Butler argued that in the process of coming into being individuals are moved to reproduce the characteristics of the representation of the ideal subject which is presented to them. However, she contends that through these acts of reproduction, referred to as performative iterations, aberrations occur. These aberrations, Butler argues, are the subject's interpretation and reformulation of the ideal subject and they thus serve to produce alternative formulations of the ideal subject. For Butler then, even though, through subjection ${ }^{3}$, individuals discipline themselves, through performative iterations they also succeed in enriching the representation of the ideal subject imbuing it with alternative formats which can be taken up and embodied by other subjects, eventually enabling them to perform themselves in a variety of ways. We thus bring these ideas to the fore in our two-year participant observation conducted in the CSR department of a French multinational company. We follow the activities of two CSR managers involved in a Base of the Pyramid project and show that whilst they iteratively cite the conventional managerialist logic, infused with accounting metrics, they also infuse their own personal desires in performing the project and, in so doing, they incrementally shift the firm's basis of engagement with the project's intended targets namely, impoverished West African populations.

We therefore suggest that embedded in these projects is the potential for them to serve as platforms for reformulating CSR practices and the CSR business case discourse. However, consistent with Butler's arguments, we show that individuals have limited capacity to stray from the normative representation of the ideal subject - that is, if they stray too far, they encounter difficulties in making their actions recognizable and accepted by others. For Butler (1990, 1993, 1997b, 1997a), the process of foreclosure comes into play, requiring the individual to pull themselves closer to an acceptable version of the ideal representation so as to render themselves intelligible to others. In this case, we thus illustrate situations where CSR managers stray too far from the representation, fail to meet their desire to be recognized by others and foreclose themselves to demonstrate to other organizational actors that they are aligned with business expectations and meet the standard of the ideal employee.

In illustrating the performative agency of CSR managers, the paper attempts to make two contributions. Firstly, by conceiving the CSR business case as a discourse of power, we show that

\footnotetext{
${ }^{3}$ In the Foucauldian accounting literature, the word 'subjectivization' is often used to denote the process by which the subject emerged from power. In her introduction to The Psychic Life of Power: Theories in Subjection, Butler explains that 'subjection' signifies the process of becoming subordinated by power as well as the process of becoming a subject. (Butler, 1997a). To ensure consistency with Butler, we use the word 'subjection' throughout this paper.
} 
even if CSR managers are disciplined by the financial logic of the business case and frame their project in financial terms, such framing enables them to gain credibility, opening up opportunities for them to reformulate the basis upon which their organization engages with its local environment. We therefore show that even if subjects discipline themselves through discourse, the repeated citations of this discourse which such subjection demands also allows for the possibility of incremental and marginal change to this very discourse, so producing slight transformations of it and therefore creating a space for alternative possibilities of subjection. Thus, this paper allows us to think of the possibility of agency emerging from the disciplinary process of subjection. This has important implications for accounting research which has so far focussed primarily on the production of the subject through the disciplinary effects of accounting. We show that accounting can also be enrolled by a subject as a legitimating resource empowering her to act on her own subjection albeit in a somewhat circumscribed way.

Secondly, by studying tensions between the performative reproduction of the dominant discourse and desires to act for the well-being of impoverished populations, we revisit the classical dichotomy between organizations and civil society, on which much of the CSR accounting research has been built. We show that CSR managers driven by their desire to work for what they perceive to be the interests of the impoverished populations position themselves as attempting to make their voices heard within the firm, thus rendering the boundary of this classical dichotomy porous. Thus, this paper highlights the fluid position of organizational actors, who, because they belong to a multiplicity of social spheres carry issues and values from the 'outside world' into the organization. Thus this paper reinforces the idea that what happens within the organization is not only the result of the organization's will and organizational culture but as well of what happens in actors' multiple environments. This paper therefore shows the complexity of the links between the firm and its environment through actors involved in the production of any sort of accounts by taking into consideration the diversity of the spheres wherein these accounting actors evolve.

The structure of the paper is as follows. We first discuss the literature which views CSR discourse as a discourse of subjection and consider the potential for the CSR subject to momentarily challenge this dominant discourse. Second, we describe Butler's framework of performative agency to explain how it provides an opportunity to consider the possibility of a subject to include some element of their personal desire, whilst enacting the disciplinary mechanisms of power. Third, we present our case study and research method and in the fourth section of the paper we present the 
empirical analysis of our case. We end the paper with a discussion of the contributions of our study and a short conclusion.

\section{CSR discourse, accounting research and subjection}

\subsection{Social and Environmental Accounting: A vector of the CSR business case discourse}

Social and environmental issues have been taken up by the accounting literature since the early development of the societal and behavioral accounting research project (O'Dwyer and Unerman 2016). This literature focuses primarily on the development of social and environmental reports as a medium between business organizations and their stakeholders, and sometimes top managers and their stakeholders (Roberts 2003), in order to establish a fair, moral and democratic dialogue between them (Gray 2002). However, by analyzing CSR reports, accounting research has shown that the discourse emanating from accounts serves mainly to protect the firms' interests (Spence 2007, 2009; O'Dwyer 2003; Cooper and Owen 2007). It is therefore argued that the discourse embodied within social and environmental reporting is a fake promise of democracy (Unerman and Bennett 2004) since it supports the neoliberal agenda (Archel et al. 2011; Banerjee 2003; Sikka 2011) by normalizing and disseminating the business case for CSR (Spence 2007; Archel et al. 2011; Spence 2009). For example, Spence (2007) points to the hegemonic ends served by CSR reports, showing that by deploying the metaphor of balance, such reports present the interests of business as largely congruent with social and environmental well-being, thereby synthesizing the interests of various social groups around the fundamental aims of business (p. 874). Meanwhile, Archel et al. (2011, p. 340), examining the Spanish case, show that this logic has been embraced by a range of stakeholders such as trade unions, which now have come to accept the corporatist concern for wages and jobs, contrary to the interests of their own membership. Capitalist logic thus emerges as the solution to all social and environmental problems and, as a result, as argued by Boltanski and Chiapello (1999), CSR discourse works to reintegrate a social critique of capitalism into capitalism itself, thereby making it even stronger. From this standpoint, researchers have therefore made strong calls to repoliticize social and environmental accounting research (Spence et al. 2010; Brown and Dillard 2013b; Brown and Tregidga 2017) and to develop alternative and more inclusive forms of reporting in the form of counter accounts (Brown 2009; Brown and Dillard 2013a; Alawattage and Fernando 2017). 
Whilst these authors focus on CSR as an instrument of diffusion of the business case to constituencies external to the organization, others focus on the internal dimension. Margolis and Walsh (2001) suggest that presenting social performance as a vector of financial performance increases morale among employees, which enables the firm to operate more effectively and efficiently (p.12). Shamir (2004) focuses on the potential disciplinary effect of CSR discourse on individual organizational members, suggesting that the CSR 'business model formula often signifies the transformation of CSR into an element of the corporation's normative control apparatus over its own employees. [...] [Thus], corporate employees develop stronger commitments to socially responsible companies than they do to indifferent ones' (p. 683). He goes on to argue that CSR discourses, programs and practices serve 'to guide employees to act in the best interests of the firm by creating an internal commitment and a strong identification with the company goals' (p.683). Costas and Kärreman (2013) develop this point by showing that 'CSR discourses and practices serve to construct an idealized image of a socially, ecologically and ethically responsible corporate self (p.394), operating as a management control too. Thus, according to Shamir (2004), CSR managers function as agents of the corporation's normative control apparatus by reproducing the discourse of control through the development of CSR programs which in turn inform the widely diffused CSR reports, which present the organization as 'doing good' for the society.

We follow this line of argument and in this paper we conceptualize the CSR business case as a discourse governing populations (Foucault 2004b) outside (toward external stakeholders) and inside organizations (toward employees) to disseminate the view that capitalist firms are the best actors to take care of the well-being of society, primarily through the deployment of their CSR initiatives. CSR managers are knowledgeable subjects who generate the CSR business case discourse through a specific accounting technology, namely CSR reporting. In so doing, they reinforce the idea that corporations are the moral agents of society and therefore serve to reinforce the hegemony of the capitalist business system.

As active subjects of the CSR business case discourse, CSR managers are the first to be governed and therefore to be subjectivized by this discourse, which they co-produce. Thus, our aim is to highlight the process of subjection of the agents producing this hegemonic discourse. We therefore offer a slightly different but complementary perspective of CSR than the extant accounting literature, which has focused on revealing the critical elements of the business case discourse contained in sustainable reporting and on considering its implications for society. 


\subsection{Accounting, subjection and the possibility of agency}

In our attempt to explore the process of CSR manager subjection, we follow Shamir (2004) and conceive of the CSR business case discourse as part of the wider set of managerial discourses operating as an apparatus of normative control that aims to ensure shareholder value maximization. It is therefore a discourse that relies heavily on accounting. The management accounting literature has examined the process through which financial discourses and accounting technologies participate in the process of subjection to produce a governable person (Miller and O'Leary 1987). Inspired mostly by Foucault (1975), accounting devices have been conceptualized as contributing to the production of a behavioral ideal against which the subject can measure herself and conduct comparisons with other workers (Roberts 1991; Miller and O'Leary 1987; Hoskin and Macve 1988; Hopper and Macintosh 1993; Miller and O'Leary 1994). Through a disciplinary process, the individual seeks to conform to this image because of a desire to secure the recognition of management and other workers (Roberts 1991). Thus, for an employee, the comparison of her performance with a predetermined objective enables her to objectify the quality of her work as well as herself (Townley 1996; Roberts 1991).

However, Roberts (1991) insists that subjection should be understood within the overall organizational context. Thus, the subject emerges not only from disciplinary aspects of accounting devices (e.g. hierarchical forms of accountability), but also through social relationships, which render hierarchical forms of accountability bearable. Furthermore, Arrington and Francis (1993), Sinclair (1995) and Messner (2009) show that individuals face multiple demands for accountability emanating from different communities with whom they share values and which participate in the process of subjection. Arising from their personal and ethical convictions, some individuals may belong to groups such as unions, churches, political parties and charitable organizations, which may call on them to account for actions for which they are held hierarchically accountable by their employers. Indeed, even without being directly involved in civil society groups, employees may have moral values derived from personal ethics (Schweiker 1993). These multiple accountabilities ${ }^{4}$ interact with the disciplinary process of subjection operating through accounting devices and may create conflicts within individuals, eventually disturbing the process of subjection (Roberts 2009; Messner 2009; Butler 2005). As a result, the individual may attempt to resist the discipline of hierarchical forms of

4 These other forms of accountability also rely on discourses that the subject reproduces and therefore participate into the general disciplinary process of subjection. 
accountability to fulfill other forms of accountabilities ${ }^{5}$, all of which rely on different discourses. Thus, CSR managers, like any other managers, emerge as subjects not only from the discipline of a singular managerial CSR business discourse, but from a complex web of disciplinary discourses relying on multiple forms of accountabilities. Some of these may be in conflict with one another, causing CSR managers to experience internal tensions with respect to the CSR business case discourse. In light of these internal tensions, the CSR manager may attempt to resist the discipline of the CSR business case discourse in order to realize herself through the disciplinary reproduction of other forms of accountabilities.

Nonetheless, the relationship between resistance, agency and subjection is a complicated one. Roberts (2005) explains that resistance is constructed in reaction to the disciplinary process of subjection. So too is the identity of the 'resistant'. The individual who resists, resists the disciplinary process of subjection, which itself calls for more discipline. The formation of the identity of the resistant operates through discipline. The subject is thus trapped in what Zizek (1999) refers to as a deadly embrace wherein more resistance leads to more power and therefore more discipline. Roberts (2005) thus concludes that agency could only be exercised through subjection (p. 638); that is, a person cannot resist subjection directly, but can only accept subjection, act on it and therefore resist through it.

In his later works, while investigating sexual morals, Foucault (1984) argued that even if the individual is disciplined by moral codes there are various ways for the subject to comply with such codes and therefore subjectivize herself. For Foucault (1984), because the subject acts on her process of subjection to conform to the moral codes, she produces her own version of the moral codes and therefore becomes an actor of her process of subjection. In that regard, Butler (2005) points out that:

'Whereas in his earlier work, [Foucault] treats the subject as an 'effect' of discourse, in his later writings he nuances and refines his position as follows: The subject forms itself in relation to a set of codes, prescriptions or norms and does so in ways that not only (a) reveal self-constitution as a kind of poiesis but (b) establish self-making as part of the broader operation of critique (p.17).

Foucault (2001) refers to these practices as the ethical aeskesis, that is, a progressive transformation of the self by the self (Munro 2014), enabling self-formation (Townley 1995). Through the process of self-formation, the subject is not only objectified through disciplinary

5 This element supports the observation by Spence (2007) that it is possible for CSR managers to deviate from the business case strategy and to try to act more in line with their own will rather than with what is recommended by the organisation. However, he cautions that this is limited by macro power structures that place business case parameters around CSR (p.874). 
techniques, but takes part in her own subjection as actor acting on it, as in the case of management accountants described by Lambert and Pezet (2011) who constitute themselves as producers of truthful knowledge. This creates a space for the person to perform her own version of the disciplinary mode of subjection (Foucault 1984). Thus, Randall and Munro (2010) show how health care practitioners bypass the statutory system to develop practices they perceived as effective for the well-being of their clients. In this line of thinking, employees therefore possess a certain degree of individual agency to realize their mission according to their own vision of how this work should be done. Put differently, they have the capacity to exercise some creativity in the interpretation of the dominant discourse in a manner closer to their sensibilities. With respect to CSR managers, this suggests that they also have the ability to reinterpret the dominant CSR discourse so as to produce a version of themselves more aligned with what they feel reflects the other accountability relationships in which they are embedded.

However, Foucault (1984) cautions that if different subjects subjectivize themselves slightly differently through various interpretations of a code thereby producing variations of this code, each subject may not recognize all alternative forms of subjection as conforming to their understanding and therefore their reinterpretation of the code. Therefore, CSR managers may be then perceived as 'different' or indeed deviant and not aligned with hierarchical expectations. Thus, reinterpretation always runs the risk of misrecognition. Building on Foucault, Butler (1990, 1993, 1997a, 1997b, 2004, 2005) is interested in understanding how, through a different reinterpretation of "sets of code, prescriptions or norms" (2005, p.17) ${ }^{6}$, the subject can act to extend the possibilities of subjection. She specifically focuses on understanding the mechanisms that enable and constrain the subject to a) participate in her own subjection by integrating some elements of her own desire and b) construct alterity through power and eventually transform the sets of code, prescriptions or norms ${ }^{7}$. Therefore, in the next section, we explore Butler's work on performative subjection in order to understand how CSR managers might construct themselves through the reproduction of the dominant CSR discourse of the business case, yet deviate from it to follow their own convictions and in so doing lay the seeds for incrementally shifting this dominant discourse.

\footnotetext{
${ }^{6}$ Although Foucault (1984) explores moral codes - that is, codes of conducts that govern sexual behavior - Butler (1990) extends this notion from the conduct of sexuality (Foucault, 1984) to any 'set of codes, prescriptions or norms' governing subjection.

7 While Foucault evokes the possibility of changes in the dominant discourse by subjects and populations of subjects through the notion of counter-conduct (Foucault 2004a, 2004b), he does not elaborate on how these changes operate.
} 


\section{Alterity, subjection and incremental change}

Butler is primarily interested in how individuals (such as homosexuals and women) brought up in a male dominated society in which heterosexuality is the norm can constitute themselves through power, but slightly differently from what is expected (Butler 1990). Her theoretical project is grounded in 'a refusal to accept essentialism in any form' (McKinlay 2010, p 236). In a number of studies, Butler (1990, 1993, 1997a, 1997b, 2004) develops a series of concepts, including representation, performative iterations, and foreclosure, to explore the process that enables the subject to come into being.

For Butler (1990), a person constitutes herself as a subject in regards to general, ideal, normative and socially desirable representations of identity, which in Butler's terms correspond to normative frames of expected identities imposed on the person. It is thus an ideal type that the person attempts to reproduce in order to come into being and to be identified as a subject. As McKinlay puts it, individuals are not 'free to choose an identity in a way they might select an outfit' (McKinlay 2010, p 234), but with respect to gender, for example, representations correspond to the cluster of characteristics that enable a person to be distinguished as a man or a woman. According to Butler (1997b) those characteristics must be reproduced by the individual in order to be identified as one or the other gender and is motivated by the individual's desire to be recognized by others. Thus, representations serve to govern the process of individual subjection. In other words, the process of subjection takes place through the disciplinary reproduction of the expected behaviors contained within given representations.

Performative iterations are acts that cite and mimic representations (Butler 1993) and are similar to the performance of actors in a play (Butler 1988). Thus, social actors perform representations through discursive and body languages in order to construct their identity and, like actors in a play, they cite the character's lines and mimic their body language in order to become the character. However, unlike actors in a play, the roles of social actors do not end when players leave the stage since there is no off stage (Butler 1988), meaning that they constantly perform the character in successive iterations. This ongoing enactment of the performance enables the subject to constitute herself in accordance with representations and therefore to be identified by others as belonging to a certain identity. At the same time, representation should not be understood as entirely static, but rather as being constantly produced and reproduced through the actors' performative iterations.

The ideal representation is broad and is reinterpreted differently by individual subjects. Butler (1997a) contends that individuals are also subjects of desire, and such desires orient performative 
iterations. The desire can come from various sources - the desire to be emancipated from male domination, the desire related to love when involving a same-sex partner, or the desire emerging from calls for compliance with other forms of accountability (Arrington and Francis 1993; Messner 2009; Roberts 2009; Sinclair 1995). Butler (1990, 1993, 1997a, 1997b, 2004) is particulary interested in understanding how a female subject, despite the necessity of reproducing the representation of the ideal female identity embedded within a discourse of male domination, might momentally escape this domination in order to construct herself sligthly differently and in a way that is more aligned with her own desire to be a woman beyond male dictates. In the case of the CSR manager who must comply with the dominant discourse of the CSR business case, her personal convictions might impel her to perform this discourse in a way such that her subjection is more aligned with other forms of accountability. Thus, subjection operates through a performative process which, though constrained, provides openings for subversive emergences (Borgerson 2005, p. 70) endowing the subject with a capacity for action that is aligned with the individual's own desires. By reproducing and performing the representation, the person can reinterpret some of its characteristics and subjectivize herself slightly differently from the idealized norm. The expression of this difference is only possible through a referential opposition to some clusters of the representation. This implies that the subject has to perform the representation to subjectivize herself, so as to eventually provide a variation of it. For instance, a woman who iterates the female representation yet at the same time asserts her sexual preference for women constitutes herself at the edge of the representation - that is, by assuming some but not all of the pre-given representations of gender. She will never be considered a male subject, but she will certainly be considered at least for some time as deviating from the female representation; and by constituting herself through this difference, she creates some space to construct herself as a woman according to her own desires.

Moreover, and critically for Butler (1990, 1993, 1997a, 1997b, 2004), these alternative variations of the representation make visible new possibilities for subjection and by doing so extend the possibility for embodying the representation that others might eventually take up and reproduce in their own process of subjection. Thus, the process of performative iterations, by multiplying the alternatives of the representation, creates spaces to extend the representation and enables the transformation of the representation governing subjection.

To summarize, when the subject acts to reproduce a representation of identity and therefore becomes a subject in conformity with social expectations, she is empowered in her capacity for action. This in turn enables her to constitute herself at the margin of social expectations, according 
to her own desire, and so slightly reconfigure the representation to a more diverse set of possibilities. Thus, if the subject is constituted through power, this power recasts the subject (Butler 2004) and gives her some possibility to constitute herself as a subject also following her own desires. As Butler points out: 'the agency of the subject appears to be an effect of its subordination', (Butler 1997b, p. 12); in other words 'an effect of power' (Butler 1997a, p. 140) and, as a result, the representation itself is enriched through individual and various performative iterations.

However, the process of changing norms of subjection is restricted since at any given time the social body limits the possibilities of extension of representations and therefore the possibility of constituting one's identity outside of given representations. Foreclosure operates concomitantly with iterations (Borgerson 2005). If iterations "make the subject" through citations and mimicry of the representation, foreclosures highlight the unspeakable, the regime of censorship (Butler 1997a, p 139), or what serves to 'undo' the subject (Butler 2004). Thus, subjectivity can be considered 'the outcome of a process of social organization through which certain performative acts come to be recognized as viable subject positions whilst others are disavowed' (Riach et al. 2016, p. 2074). The constraint of foreclosure as exercised by the social body is enacted both externally - through interactions with other individuals - as well as internally - through a reflexive and disciplinary process exercised by the subject on herself, following her desire to be recognized by others and the internalization of the representation by the subject, both of which operate concomitantly. Therefore, Butler's critical project is to expose the mechanisms of subjection which, through the reproduction of the dominant norm, facilitate the construction of alternative identities that reinvent a current ideal type that is acceptable to the social body.

In the case that follows, we seek to illustrate the ways in which CSR managers act and perform in their daily work in accordance with the discipline of dominant managerial discourses (including CSR business case discourse) and their personal desires. Our interest lies in the possibilities embedded within performative iterations to extend and incrementally transform the representation of the CSR manager embodied within the CSR business case discourse, and we will reveal the mechanisms of foreclosure that work to limit the extension of the representation of the ideal CSR manager embodied in the CSR business case discourse. 


\section{Case Study}

\subsection{The setting and the actors}

\subsubsection{The Company}

The company we studied, referred to here as Firm H, is a large publicly traded French multinational corporation specializing in telecommunication services. It operates mainly in Europe, Africa and the Middle East. Firm H was previously a public utility that formed part of the Ministry of Posts and Telecommunications. In 1988, pursuing a neoliberal agenda, the French government converted Firm H into a state-owned company, later privatizing it 1997. Currently, the French state remains the largest shareholder, but is no longer the majority shareholder, owning $27 \%$ of Firm H's shares.

This move from a public utility to a privately-owned company changed employees' understanding of their primary stakeholders. Previously, as part of state bureaucracy, the ultimate mission of Firm H's employees was to provide the best service to citizens. Firm H's transformation into a private company supplanted this vision with an accountability directed toward shareholders and a single objective defined in terms of maximizing shareholder value. This shift established a new hierarchy amongst the firm's business functions. Thus, even though in structural terms departments are organized as if they are of equal importance, the proximity of some to shareholder value maximization unofficially placed them at a higher rank within the organization. In the pecking order, CSR was positioned below Marketing, which itself was positioned below Finance.

Before being privatized, the company only operated in France. In the 2000s, Firm H started to buy local telecommunication companies throughout Europe, Africa and the Middle East. At present, the company ranks first or second in the market in $75 \%$ of European countries and operates in $83 \%$ of African and Middle Eastern countries, and with revenues of $€ 40.9$ billion in 2016 , it is one of the 50 largest European multinational companies.

The company has its headquarters in Paris. It also has several R\&D sites spread throughout France, Egypt, Jordan and Côte d'Ivoire, as well as several business units responsible for commercial and marketing activities in each country where the company operates. Most of the firm's new products are created by various teams located within the corporate marketing department in Paris, but later developed by each of the business units. When the business model for a new product or service is approved, head office sends it to the business units, which then adapt the product or service to local market specificities and commercialize it. 


\subsubsection{The CSR department}

This study focuses on managers working within the Corporate CSR department located in Paris and their relations with corporate marketing employees responsible for developing new products and services. The CSR department is organized into five groups. One group is dedicated to communications and the construction of the yearly CSR report. Another is dedicated to environmental matters. The three other groups work to infuse CSR into the overall business practices of Firm $\mathrm{H}$ by assessing stakeholders' expectations for each business unit (Team 1), coming up with socially innovative products (Team 2) and developing innovative tools and processes (Team 3). All the members of these teams are directly or indirectly accountable to Richard, the head of the CSR department.

$$
<<\text { Insert Figure } 1 \text { about here }>>
$$

\subsubsection{Targeting low-income consumers}

The idea to develop specific products or services targeting low-income consumers at Firm $\mathrm{H}$ should be viewed in the context of French multinationals operating in the mass consumer market. Most of the Executive Directors of these companies, including CSR directors, are graduates of elite Parisian schools ${ }^{8}$. They belong to the same social circles, meeting regularly to exchange ideas about their practices. Because of this proximity, an innovative practice in one company is often quickly taken up by others. For example, in 2006, in the aftermath of the widely publicized joint-venture between DANONE and Grameen Bank, the idea of targeting low-income consumers quickly spread ${ }^{9}$ and many French multinational companies, through their CSR departments, began to develop their own programs focused on the low-income populations of the Global South. At Firm $\mathrm{H}$, the Grameen-DANONE program was regularly held up as the paradigmatic case.

At the time of the study, Firm $\mathrm{H}$ focused on two different activities in West Africa. First, it sold SIM cards and telecommunications minutes through scratch cards to every segment of the population, enabling cell phone communication to every client ${ }^{10}$. Second, the firm developed specific and high value services for the urban upper classes with needs similar to French urban populations

\footnotetext{
8 The French administrative and economic elites are trained in the same elite schools, known as 'Grandes Ecoles'; for more information, see (Suleiman and Mendras 1995)

9 The joint venture between DANONE and Grameen Bank aimed to sell affordable and nutritious enriched yogurts to Bangladeshi children from low-income families (see Yunus et al. 2010)

${ }^{10}$ However, the telecommunications network did not cover all West African territories. Urban areas were better covered than rural areas. Nevertheless, even within rural areas not covered by the network, villagers own cell phones and buy telecommunications minutes when travelling.
} 
(e.g. 3G service, telecommunication plan with iPhone, etc.). Although the company was working on a new plan to develop specific services for the other West African income groups, rural populations were excluded from the plan since they were considered too poor to be viable consumers in meeting the firm's growth objectives.

\subsubsection{The rural lab}

Though not in accordance with the development of the marketing plan previously described, the CSR department started to develop the rural lab, the project examined here. It was established in an attempt to create a CSR Research and Development unit in Côte d'Ivoire with a view to experimenting with new methods of collecting information about West African low-income rural populations. It was envisaged that the information would be collected by a local agent who would travel from village to village asking questions among rural populations about their daily lives to better understand their needs. The local agent would have embedded in their cell-phone an electronic database with a search menu that would help him/her to provide specific agronomic information to the rural villagers.

The rural lab project was proposed by two CSR department employees, whom we will refer to as Paul and Charlotte. Paul and Charlotte believed that the corporate marketing department might help to develop the project. The corporate marketing department would be the primary beneficiary of the project in the long run since it would use the information gleaned to develop new products and services for the target populations.

\subsubsection{Paul and Charlotte}

This study focuses on Paul and Charlotte, the two managers working on the development of the rural lab and the individuals in the firm with whom this paper's lead author primarily worked. This proximity enabled a better understanding of how they made sense of both their actions and themselves.

Charlotte was hired by Firm $\mathrm{H}$ in her early twenties shortly after graduating from a Business School program. She later obtained a master degree in Sustainable development, returning to Firm $\mathrm{H}$ upon completion. Paul joined Firm $\mathrm{H}$ in his mid-twenties after having worked for Firm H's main competitor for around two years. Both were hired in the second half of the 1990s. In keeping with the firm's HR policy that employees should stay in a position for 3 years, they had both occupied different positions within the company before joining the corporate CSR department. Within the 
CSR department, Charlotte was a member of the team in charge of external relations with stakeholders. Paul was responsible for implementing CSR practices within the firm and therefore acted as the liaison between the CSR department and the corporate marketing department. As regards the division of tasks for the rural lab project, Charlotte was in charge of defining a method to collect the information from the West African villagers, whilst Paul was the project manager.

\subsection{Research Methods}

\subsubsection{Data collection}

An agreement was reached between the CSR department of Firm H and one of the authors, allowing her to work closely with Charlotte and Paul between September 2010 and July 2012. The researcher was expected to help the company better understand the impact of two of its existing business programs targeting low-income populations in West Africa and eventually to develop a reporting tool for highlighting the impact of the firm on poverty reduction. In compensation, the researcher was free to investigate other topics as her investigations progressed.

On average, the researcher was present in the firm on one and a half days a week for fieldwork purposes, either for meetings with Charlotte and Paul or for meetings involving a larger group of employees. This allowed her to observe debates and other interactions between the CSR employees and some of their colleagues about projects such as the rural lab. Many of the meetings started or concluded around a meal or a beer at the cantina. Such events helped the researcher to collect supplementary information informally.

At the end of the two years, final interviews were conducted with most of the actors with whom the researcher had been in contact during her two years of research. This final series of interviews involved many actors from Firm H's CSR and marketing departments who had worked on product development for Africa. Charlotte declined to be formally interviewed in 2012, but the researcher who collected the data remained in contact with her. Charlotte eventually agreed to be interviewed in 2016. The characteristics of all the interviews are provided in Table 1.

$$
<<\text { Insert Table } 1 \text { about here }>>
$$

Four types of material generated from the ethnographic study were used to provide the empirical data for this paper. The first were logbook materials. The researcher kept detailed records of conversations and encounters during data collection in a field research logbook. In addition to the verbatim logbook, the lead author maintained another logbook, in which memories and reflections related to this academic project were recorded. We refer to this in the paper as a reflexive logbook 
(Nadin and Cassell 2006). The type of material were transcripts of recorded meetings. These were meetings in which the lead author had a formal role to play with respect to the development of the company's reporting tool. The recorded meetings were transcribed by a professional transcription service. The third type were transcripts of interviews, also transcribed by a professional transcription service, and the fourth were copies of PowerPoint presentations developed by Paul or Charlotte to present the rural lab to their colleagues.

Since all the fieldwork was conducted in French, the above material was translated into English by one of the authors for the purposes of the paper, taking into account the meaning of each word in context as much as possible in order to arrive at the most faithful translation.

\subsubsection{Data analysis}

Our data analysis involved four steps: inductive coding of the data; analysis and interpretation of the context in relation to inductive findings; reflecting on the theoretical lenses; and self-reflexivity (Alvesson and Sköldberg 2009; Girei 2016). Intertwining various stages of reflexive interpretation in this process enabled us to make sense of the data and attribute meaning through an iterative process (Becker 1998), which began during the data collection period and continued in the following years, during which the production of written essays and schemata continued to refine the theoretical interpretation of observed phenomena. While collecting the data and reviewing the transcripts, we noticed a series of emerging tensions at the department level (e.g. CSR versus the marketing department and, to a lesser extent, CSR versus the finance departments), between various levels within the CSR department (Richard versus Paul and Charlotte; Charlotte versus Luc, Paul versus Daniel) and at the same hierarchical level (Charlotte versus Paul), but also within the individual (Charlotte versus Charlotte; Paul versus Paul). Although these tensions were pervasive and were characterized by different levels of intensity, all of them involved a binary tension between the well-being of the local population and profit and between personal perceptions of how low-income populations should be treated and duty to the firm. Regardless of level within the organization and the specific people involved, these tensions were palpable. On the one hand they involved the normative question of how to be a company that 'does good' and how to be a subject who 'does good' within the company. On the other hand, was the organization primary goal, namely to make a profit, all of which collapsed in their minds into the broader question of how to transform the company in order to make it become more sensitive to the needs of local impoverished populations. 
Following Becker (1998), we were looking for an unexpected element in our fieldwork. What struck us during the first level of interpretation (i.e. inductive coding of our data) was that CSR employees seemed to have internalized these tensions were constantly struggling to position themselves through these tensions. They were found to regularly rationalize their behaviors, and their rationalizations constantly involved marrying financial expectations with personal concerns about justice toward the local populations.

The second level of interpretation was the contextualization of these tensions through histories of the firm, which was necessary so as to better make sense of the data, of the CSR department and of each person working in the CSR department, considering their interests and convictions.

The third level of interpretation related to the theoretical lens used to make sense of the data. We initially considered what we were observing as a process of subjection through hierarchical accountability, which has been well examined in the Foucauldian accounting literature (see, for example, Jeacle 2015; Roberts et al. 2006; Hoskin and Macve 1986, 1988; Hopper and Macintosh 1993; Preston 2006; Graham 2010; Jeacle and Walsh 2002). Although a disciplinary process clearly emerged from the data, the concept of discipline did not seem to adequately capture some of the actions of the actors. Indeed, at various points the behavior of actors appeared to be inconsistent with such a process. Instead we found that these different elements fit better with concepts deployed by Judith Butler in various writings, leading us to rely heavily on her analytical lens in order to make sense of the phenomena that emerged from the earlier analytical steps. We attempted to capture Butler's concepts in the following ways. First, regarding the notion of representation, we reviewed all of Firm H's materials with respect to the mission of the CSR department, its position vis-à-vis other departments and the CSR mission of the CSR managers and what was expected of them. We supplemented this with discursive accounts from Paul and Charlotte's interviews as well as logbook entries so as to capture their perceptions of the nature of the representation applicable to them. Second, in order to gain a precise understanding of Charlotte and Paul's performative agencies, we focused our attention on the PowerPoint presentation describing the rural lab, Paul and Charlotte's interviews and logbook entries relating to Paul and Charlotte's discursive accounts. Within these materials, we identified elements of mimicry, citations and evidence of opposition. The evidence of opposition helped us to identify attempts of marginal incremental change.

The final level of interpretation - self-reflexivity (Bourdieu 2001) - entailed critical analysis of the process of data collection and analysis, particularly in terms of the role of the researcher while in 
the field. In contrast to the three previous levels of interpretation, which were more or less sequential, self-reflexivity occurred throughout the research process and beyond. Particular attention was paid to the relationships that the researcher who undertook the data collection might have developed with the people she encountered in the field and to the values or personal behavioral characteristics she might have shared with those people and how that would have shaped data collection and interpretation.

\section{The rural lab, alterity and the production of incremental change}

\subsection{The background of the rural lab}

\subsubsection{Technology and profit maximization as key clusters in the representation of Firm $H$}

The representation governing employee subjection was based on two clusters, both of which were grounded within the culture and the history of Firm H. These clusters defined the general orientations that employees performed in order to subjectivize themselves as recognizable Firm $\mathrm{H}$ employees. First, the company as an ex-public utility embodied the characteristics of most of the French industrial jewels that were, and to some extent still are, at the center of French economic policy. In other words, Firm $\mathrm{H}$ had a technological culture and relied on one of the most important professional elites in France: engineers. Any department, including the marketing department, employed engineers, with a high proportion coming from the elite Ecole Polytechnique engineering school. This was even more true of managerial positions. For instance, the head of the marketing division for the Africa and Middle East zone trained as a telecom engineer and later obtained a master's degree in finance. Thus, the Vice-deputy for the Africa and Middle East zone, who, unlike most of his colleagues, trained in a business school (majoring in marketing), reports;

'Our culture, it's - I saw it again in the official documentation recently - a full chain of three events: we invent, we produce, we sell. It's a vision which is by nature hyper techpush. And even if we try to work on this and infuse more and more market knowledge... The gene of the company is all about technological products. (Vice-Deputy for the Africa and Middle zone, June 2012)

Technological projects were valued and many employees, including many marketing professionals, viewed the technological value of a product as the main feature attracting consumers. Understanding the importance of technology and the ability to participate in technological product development and to produce technological artefacts was a key feature of Firm H's DNA. Therefore, this was inscribed within the representations of Firm H's ideal employees - including marketing 
professionals. The focus of marketing employees was on product development, thereby making issues such as competitors and consumer perspectives, which are typically considered key to marketing performance, secondary matters. The branding and the image of the company were therefore constructed around this technological perspective and driven by the idea that technological value attracts consumers.

Second, despite or, more likely, because the state was the largest shareholder, there was a strong emphasis within the organization on profit maximization. In the following quote, a senior executive manager explained:

But in Firm H, we're in a company that's too short-term oriented. [...] The state pushed for this financial evolution. When you think about the fact that the state is by far the largest shareholder and the second main shareholder owns what, I don't know, 3\%... Well, the state does whatever it wants in Firm H [...]. It pushes for crazy dividends ${ }^{11}$. $[\ldots]$ There's no social vision in Firm H. [...] I, I think Firm H is now a company where financial pressure is extremely high because of the crazy levels of expected dividends. We need cash, so we operate based on share value only. (Senior Executive Manager in charge of operations in three African business units, May 2012) ${ }^{12}$.

While, as a public utility, Firm $\mathrm{H}$ employees were governed by a representation that put services to citizens and access to telecommunication for all at the center, when the firm was privatized, this aim was supplemented by profit maximization for shareholders. According to the quote above, this new aim left no space for a societal vision. Top managers were responsible for providing dividends and therefore managed people on the basis of this new goal only. Employees were now expected to carry out actions that supported shareholder value maximization. In short, they were expected to behave as employees of a large private company and not as civil servants. This change in objectives also transformed the normative representations of employees. In the early 2010s, the representation of Firm H's ideal employee was one in which the idea of shareholder value maximization was central.

\subsubsection{The representation of the ideal CSR employee}

At least from 2008 and until the end of the data collection process, the CSR department appeared to be a department looking to define its area of competence. This made the reinterpretation of the representation more open but also more hazardous for CSR employees.

11 In a context of low-growth policies and tax cuts, the French state was looking for cash by any means.

12 It is worth recalling that between 1988 and 1997, the state's ownership of Firm H reduced from 100\% to 27\%. During that period, the neo-liberal French state acted like a typical stock market actor, seeing dividends and capital gains as a means of enhancing state revenue. 
Before 2008, the department mainly focused on collecting information on the social and environmental activities of Firm H and on producing the firm's annual CSR report on the basis of that information. However, in 2009, following the 2008 financial crisis, the CEO decided to appoint a new head of department in order to extend the jurisdiction of the CSR department. He appointed Richard, who recalls the following:

In 2009, the former CEO called me and said: 'Sustainable development: it's crucial! Only companies with a real societal vision will survive and will make a difference. I've decided to emphasize this. I need a guy who knows the company, who knows its strategy, its people and its leadership. That person is you! (Richard, current Head of CSR Department, interview, July 2012)

Richard was charged with the task of making CSR a key element in building the long-term value of the company. The previous head of department had originally trained in journalism and communication, while Richard was an engineer from the prestigious Ecole Polytechnique and had enjoyed a long career at Firm $\mathrm{H}$ in various prestigious positions. He had the same profile as most of the top executives who achieved executive board membership. Furthermore, as suggested in the above quoted, Richard was close to top management and was therefore perceived to be a good person to manage the CSR department in line with its technological vision. He was also felt to be more aligned with a financialized vision of the firm, placing shareholder value maximization front and center. For example, he explains:

And then the "CSR Director 2.0" is someone who actually puts CSR at the heart of the business and who reasons on the basis of decision-making criteria such as value creation and investment choices for the company. (Richard, Head of CSR Department, July 2012)

Richard thus adopted a particularly narrow definition of CSR business case discourse, confining it more firmly within the bounds of profit maximization. In so doing, he cited the cluster of the dominant representation to produce a vision of the CSR department driven by a more general financial business discourse.

As the head of the department, Richard set the expectations for CSR employees. As a result, his distinctly business-oriented vision of CSR was intended to be deployed by employees working within his department. His vision of the CSR employee was directly based on the representation of the ideal employee governing the behavior of any Firm H employee since its privatization. CSR employees were therefore expected to mobilize sustainable elements in order to help the company secure future profits. Therefore, Richard promoted a rather conservative and financialized rhetoric of CSR business case discourse within the department, framing the representation of the ideal CSR employee accordingly. 
Despite Richard's strong pedigree within Firm H, he struggled to establish legitimacy for the department. Two factors are worth noting here. The first is the context in which the department's new mandate was set out. In 2009, Firm H received significant media coverage as a result of what was deemed to be a suicide crisis - an unprecedented spate of suicides amongst employees that was thought to be linked to its cost-cutting and restructuring activities following its privatization. Whilst pre-privatization employees had retained their civil servant contracts and were therefore protected from dismissal, in an attempt to encourage voluntary resignations a regime of harsh working conditions was unleashed on those employees whom management deemed to be no longer required. Thus, in late August 2009, numerous suicides were reported to be taking place at Firm H (Chrisafis 2009) and there was a widespread belief in the country that the spate of suicides was the result of a change in management style at the company (Laigle 2016), with many victims leaving notes attributing their actions to stress and misery at work. The view at Firm $\mathrm{H}$ was that the corporate HR department had no legitimacy to manage the crisis since it had been the architect of the staff reduction plan. It was therefore decided that the task would be the responsibility of the CSR department, which would also work to reduce the impact of the crisis on shareholder and client perceptions (Richard, Head of CSR Department, interview, July 2012). As a result, Richard's appointment as head of CSR was accompanied by an increased budget and a 100\% increase in staff, highlighting the potential of CSR to repair the moral image of the firm. However, by 2010, when the suicide crisis was over, the firm was mired in the economic recession resulting from the 2008 financial crisis. This severely impacted the firm's results and its ability to meet its projected dividend payout. At general management level, the corporate rhetoric was dominated by cost reduction and the CSR department soon became an easy target of potential cuts (Charlotte, interview, February 2016).

The other issue faced by the CSR department was structural. Firm $\mathrm{H}$ had a well-established unit known as "the Foundation" which handled the firm's philanthropic activities and was understood to be the unit responsible for constructing a positive image of the firm among external parties. Therefore, in the minds of many, it was difficult for the CSR department to differentiate itself. Regarding the CSR department, a senior marketing manager observed:

[...] there is no direct link with business. Therefore, CSR is seen as a cost center, and when a cost center does not have a specific and well-identified budget that is clearly defined and protected, the center must constantly fight. For the Foundation, things are clearer. They have their own budget, and this is clearly accepted by everyone. But for CSR this is still too new. There is an educational process aimed at defining what CSR is, 
but it is not altogether clear. That is why [...] they are always subject to budget cuts.

(Corporate Senior Marketer for Africa and the Middle East, interview, June 2012)

Here the restorative effect of the CSR discourse seems to have disappeared, showing that depending on the circumstances, the perception of the CSR department's capacity to repair the moral image of the organization waxes and wanes. Richard, apparently mindful of the unit's fragile structural positioning, thus sought to link CSR with the firm's brand, thereby reframing CSR as a key variable of the firm's success. In further explaining this vision, Richard notes:

Sustainable development [...] integrated within the brand makes sense because the brand is the promise of stable behavior, the promise of long-term value. So, bringing sustainable development within the brand is a healthy thing. [...] Branding is something the guys from finance understand. [...] It adds value. They don't dispute the fact that the brand is an asset that returns money. (Richard, interview, Head of CSR Department, July 2012)

However, this only served to further weaken the CSR department within the corporate structure since integrating CSR within the corporate brand meant that the CSR department would need to work closely with the corporate marketing department, a department which did not need CSR to demonstrate its contribution to the firm's bottom line. Thus, a palpable power asymmetry emerged between the two departments such that the CSR department was required to yield to corporate marketing's expectations. This meant that CSR managers were required not only to perform the cluster of representations governing the vision of the CSR department as envisioned by Richard, but also to perform representations that conformed to the general representation at play within Firm H's corporate marketing department.

\subsubsection{Background of the CSR managers developing the rural lab}

\subsubsection{Paul}

Paul had the critical responsibility of helping the department achieve its goal of integrating CSR within the corporate brand and gaining recognition for the CSR department within Firm H. As the CSR liaison with the corporate marketing department, his actions were always subject to the scrutiny of marketing employees and he was judged based on his ability to align his actions with the representation of the ideal corporate marketing employee.

Paul had been transferred to the CSR department six months prior to Richard's appointment as the Corporate CSR Director. His was the first role within the department that went beyond the functions of CSR reporting and communication. He was specifically charged with promoting 
sustainability within the corporate marketing product development process - a cause to which he was personally committed:

Researcher: But why did you take this position in the CSR department $[\ldots]$ ?

Paul: It's the idea that you can mix professional interest with personal interest [...]. I work within a company because I think it's a good way of doing things. I have a deep sympathy with the CSR philosophy. [...] I'm convinced many things can be done through companies, which might not be the case [currently]. Regarding development issues, companies have a key role to play. [...] When you see all the limitations that international funding agency actions can have, or NGO actions [...] with the shape of [local] governments [...] at some point you need willingness from government, but in the meantime, companies can do stuff. (Paul, interview, June 2012)

This quote highlights Paul's motivations for working for the CSR department and how he perceived his role as a CSR employee. In other words, although Paul was personally committed to the societal goals of CSR, he clearly had faith in the private sector to act for the well-being of society. Therefore, Paul saw private enterprise as the institutional actor that enabled him "to do good" and therefore seemed to be personally convinced of the relevance of the CSR business case discourse. However, whilst describing what CSR business employees could do, he mainly focused on what companies could bring to society with regards to societal and environment matters, downplaying what CSR could bring to business and to shareholder value. He therefore appeared to distance himself somewhat from the financial cluster in Firm H's ideal representation, which privileged shareholder value maximization.

Paul's job description was very broadly defined, and he was given the freedom to determine how to achieve his mandate. At the same time, he had very few markers to guide him. His initial goal was to reduce the environmental footprint of products under development. However, he admitted that once he began to interact with the corporate marketing group, he discovered that many of the projects with environmental impacts also had significant social impacts.

$[\ldots]$, then when I started to look at the different offers, I saw... 'illiteracy, ... but this is CSR' and one thing leading to another, I arrived at where I was supposed to end ... I started to work with something resembling a CSR product portfolio. (Paul, interview, June 2012)

This was particularly the case with products and services that fell under the jurisdiction of the African and Middle East business units. According to Paul, engagement with these units increased his awareness of the importance of the development agenda within these countries and, as a result, he expanded his mandate to include promoting products and services with a positive impact on poverty reduction in Africa and the Middle East. Therefore, to fulfill his mandate, Paul decided to 
develop what he called a Sustainable Product Road Map ${ }^{13}$, drawing up an inventory of every product that had a sustainable potential and, for each product, attempting to elaborate a process that would enable the development of sustainable components.

To build his Road Map, Paul met managers in charge of products identified as having CSR potential to determine how their potential could be enhanced. This new aspect of Paul's mandate was considered intrusive and was not well received by corporate marketing employees. For instance, in the quote below we report the views of Jeanne, a French-Ivoirian marketing manager who was developing a product designed to connect the rural, poor and remote West African villages to the telephone network. While trying to implement her project, she encountered many difficulties in obtaining the necessary human and financial resources. At first, she put a lot of hope in Paul, but she quickly realized that his mission was not defined to help her.

When Paul came to see me ... he said, 'CSR.' I said, 'Great. I already have a product that embodies CSR, [...]. What can you do for us? Do you have people? No, fine. Do you have money? No. Do you have any leverage to help me to convince the Marketing executive committee? No.' [...] I said, 'So what can you do for me? So, for me, the only impression I get is that you're stealing my time because it's a product that helps you to gain visibility. Yes, let's call it what it is: to help you to get visible because it's an initiative that embodies CSR'. (Jeanne, during a meeting including the director responsible for marketing strategies for Africa and the Middle East and Charlotte, emphasis ours, February 2011)

Thus, the development of the Sustainable Road map was not well perceived outside the CSR department. It did not help Paul achieve his mandate nor did it help the CSR department gain legitimacy.

To perform his mission, authoritative support might have helped. However, as Paul put it, he had a complicated relationship with his superior, Daniel (Field researcher's logbook, June 2012) and although Daniel had important connections within Firm H, Paul believed that Daniel never really mobilized his network in his support (Paul, interview, June 2012). Nonetheless, Paul could have coped with this tension by working directly with Richard, who was well respected and might have lobbied the marketing directors on behalf of Paul's projects. However, Paul never dared bypass Daniel. Paul explains:

I'm too respectful of hierarchy, I guess. So, if I have an imposing and strong boss that I don't connect to, I get 'good student syndrome' [...] I should have taken more liberties. [...] After all, it's a little bit silly, you're the person who sets your own limits. [...] I wasn't

13 The Sustainable Development Road Map was largely inspired by the existing Product Road Map; in other words, whenever the Technocenter proposed a new product or service, a deployment kit covering different technological steps was also offered. Thus, when a product was deployed in different business units, technological aspects were gradually but systematically implemented. 
seeing Richard as much as I had wanted to, even though nothing was stopping me. (Paul, interview, June 2012)

Thus, because he had internalized the hierarchical discipline so deeply, Paul could not overcome the fact that in order to realize his fulfill he had to bypass his line manager. In other words, Paul's disciplinary tendency played a significant role in reducing his own ability to fulfill his mandate. To succeed in fulfilling his mandate, Paul would have to find another way to perform his task. This opportunity emerged with the rural lab.

\subsubsection{Charlotte}

Charlotte's vision of the ideal CSR employee was more radical than Paul's. Although she studied at a business school and had spent her entire career in Firm $\mathrm{H}$, she claimed:

For me, it's a bit scary, I don't have anything to do in a private company because I'm not interested in it. But there is a common principle, which is understanding humankind, that is anthropological aspects, the Dogon [an ethnic group in Mali, Niger and Burkina Faso], etc. (Charlotte, interview, February 2016).

She was therefore keen to develop projects within geographic areas that were culturally different from her Western culture and which incorporated dimensions other than profit - in particular, those which addressed issues she cared about, such as poverty reduction. Thus, on a personal level, Charlotte was much more driven by a development discourse than a business discourse. In 2008, in pursuit of her interests, Charlotte decided to return to university to study sustainable development. She pursued a program in which various economic perspectives were included, including NeoMarxist and degrowth approaches. She believed that her master's in Sustainable Development helped her develop her critical thinking skills:

It happens that I have been trained. I am an 'aware' [in English] and I think about the world's problems. I think the master's degree opened my mind about stuff I hadn't thought about before. (Charlotte, interview, February 2016)

This led her to question the impact of a company on its environment and its relationship with its stakeholders. She became critical about publicly-owned capitalist firms because of their short-term profit/shareholder focus and, as illustrated below, she articulated a strong preference for investment models requiring social and/or environmental benefits:

And this is where I don't agree $[\ldots]$ about the model in which there has to be a return on my investment at a certain moment $[\ldots]$. And unfortunately, it's only when the company is owned $100 \%$ by the state that we can do something different, or if your shareholders have different objectives: either an investment fund which is openly sustainable or an individual shareholder who decided to put his money toward a given objective, even if it returns less money. [...] but we should keep in mind that for Firm $\mathrm{H}$ this means something other than returning money to shareholders. Okay, it provides a return to 
shareholders, but the real mission of the company is about providing services to clients and nourishing its ecosystem, $[\ldots]$ and all those beyond shareholders... You have to be dumb to only consider shareholders. [...] Because who invested in the [Firm H's] networks and so on? Originally it was the state. And, then with the divestiture of public ownership... [...] (Charlotte, interview, February 2016)

Charlotte's critique of Firm H's shareholder focus provides an insight into her ideal vision of the company she would like to work for and of the role she wishes to play within it. She advocated a model in which Firm H contributes positively in order to fulfill every stakeholder's needs. She also seems to regret the privatization of Firm $\mathrm{H}$, which has supplemented the goal of access to telecommunications for all for profit maximization. Charlotte's arguments reveal a will to work for the greatest number of people without regard to their income. For her, the reconciliation of a business cluster with a societal cluster was of no importance. Therefore, in her view, the business objectives of the company were a constraint to be taken into consideration and to manage as she sought to pursue her agenda.

Nevertheless, Charlotte's position also revealed a certain ambiguity. For her, having a job that enabled her to make a change was very important, but she often suggested that she felt Firm $\mathrm{H}$ was not the right place for this. However, when considering the idea of leaving the firm to work for a charity, she was deterred by the impact of a lower salary on her Parisian lifestyle (Charlotte, interview, February 2016). To justify her position, Charlotte would convince herself that her work was meaningful by stating that corporations, particularly those engaged in the communications sector, had a specific role to play in improving the lives of the more vulnerable. This served to reinforce her belief that her mission was to transform Firm H. Ultimately, her critique was one that aimed to reform rather than abolish capitalism.

During her master's degree, Charlotte completed an internship within the CSR department of Firm $\mathrm{H}$ under the supervision of Luc, who later offered her a permanent position. She helped write her own job description and was therefore able to inscribe her vision of a more inclusive enterprise within her daily work. With the help of a consulting firm specializing in CSR, she took charge of conducting consultations with the external stakeholders of each of Firm H's business units. These stakeholders were defined as important groups within civil society and it was her job to assess their perceptions and expectations of the company. From there, in collaboration with business unit employees, she helped define strategic CSR policies to support each business unit in meeting stakeholder expectations. It can be argued that this was Charlotte's first intervention in redefining CSR practices according to her own vision since stakeholder dialogues initially aimed to collect the 
views of stakeholders and to make them heard within the company. The fact that Charlotte participated actively in defining her own mission meant that she acted to push her vision of CSR within the department.

In contrast to Paul's situation, Charlotte's mandate was relatively well defined, with specific quantifiable targets. She was expected to conduct three stakeholder dialogues per year, each in a different business unit. Therefore, compared to Paul, she had more points of reference to fulfill her mandate. Having a well-defined mandate worked in Charlotte's favor since it enabled her to go beyond what was expected of her and, in so doing, allowed her to develop other ways of promoting her vision:

Researcher: But you achieved your objectives... [because]?

Charlotte: For freedom? [pause - Charlotte thinks] Yes, that's it. It's a matter of time, a matter of acceptance [...] but you find spaces where you can act. (Charlotte, interview, February 2016)

Here, Charlotte expresses a will to go beyond her stated mandate to achieve something that seems bigger than what was expected of her by her superiors. Indeed, achieving her organizational objectives was for Charlotte a minimum duty, knowing that she received a salary in exchange. She therefore accepted the discipline emanating from the achievement of her mission, rationalizing it since it allowed her to work on other projects that were more aligned with her own vision.

Nevertheless, Charlotte explained that not all her superiors had allowed her to operate in this way, but that thankfully she and Luc had a strong relationship. Like Charlotte, Luc was convinced that their job as CSR employees was to transform the organization and turn it into a more environmentally responsible entity. He also shared with her a desire to interact with people. Luc respected Charlotte's vision to the point of including her in the process of writing her own job description. As a result, Luc gave her the space to develop additional projects besides those directly related to her mandate provided her primary objectives were achieved. As shown in the logbook entry below, he even directly encouraged her to go beyond her mandate to try to change the habits of the organization:

Charlotte tells me about her annual performance evaluation. Luc told her to keep messing up Firm H’s habits. (From the field researcher's logbook, February $8^{\text {th }}, 2011$ )

Thus, in the CSR department, Charlotte devoted time not only to conducting stakeholder dialogues, but also to the development of other projects, such as placing beehives on the rooftop of the future headquarters to promote an awareness of the global decline of bees within the company. It 
was also as a result of the desire to 'mess up the habits of the organization' that Charlotte became involved in the development of the rural lab.

\subsection{The development of the rural lab}

The genesis of the rural lab is vague. According to Charlotte, the idea of the rural lab arose out of a discussion she had in October 2010 with the CSR coordinator of the Malian business unit while working in Bamako on a stakeholder dialogue (field research logbook, January $6^{\text {th }}$, 2012). During this dialogue, poverty reduction among rural populations emerged as a major concern for several stakeholders. Charlotte realized, however, that the Malian employees of Firm $\mathrm{H}$ had very limited knowledge of rural populations, having had very limited contact with them ${ }^{14}$. Moreover, data about the group was non-existent. Therefore, she determined that it would be difficult to convince Firm H's local business unit to develop CSR programs for this population and that a directive from Corporate might therefore help.

In February 2011, Charlotte met with Jeanne and the Director responsible for marketing strategies for the African and Middle East zone. The aim of the meeting was to organize the researcher's trip to collect information on existing business programs dedicated to impoverished rural populations. The conversation shifted unexpectedly to the broader question of what role the CSR department should play in creating greater value for corporate marketing. The Director was seeking to come up with an alternative way of promoting CSR within his department. He argued that CSR employees should develop new products or services for marketing to bring to market. He thereby redefined the CSR department as a center for sustainable innovation:

I want to know how I can have a CSR lever in order to create more value for the business, but also for society; so, my perception - and I have looked at this subject from many angles - of the current process is that it's not efficient. The only way to make it efficient is to give you [the CSR department] a central role in the innovation process. Come to see us [the marketing department] with innovative ideas! (Director responsible for marketing strategy for Africa and the Middle East, during a meeting with Charlotte, Jeanne and a data collector, February 2011)

The Director clearly stated that the CSR department should be at the service of the marketing department to assist it in better performing its mission in terms of product innovation and development. Moreover, because the Director worked closely with business units from Africa and Middle East, he was particularly looking for business projects to address poverty reduction, identified as the most important issue in these zones.

14 The Malian employees of Firm H belonged for the most part to the urban upper classes. 
Accepting the proposal, Charlotte spoke to her manager, Luc, and to the head of CSR, Richard, about the idea and both agreed that it would be interesting to pursue the matter. From there, Charlotte and Paul began working more or less informally on what would become the rural lab. The first task for Paul and Charlotte was to develop the business model of the project, which

they would later present to different corporate marketing teams. These presentations would test the concept of the project itself, help them better understand the corporate marketing department's expectations and integrate them into the business model of the project. The presentations aimed ultimately to convince the marketing department to find funding solutions for the rural lab and to identify the most appropriate business unit in which to implement it. This business unit would then provide the logistical support and means to decipher the local culture in order to better deploy the project. Such presentations were also designed to help legitimize the CSR department by demonstrating to the rest of the company that the CSR department was able to develop innovative business projects that would eventually contribute to the achievement of Firm H's profit targets. The presentations were also a way for Charlotte and Paul to present an alternative path of doing business to an audience they both wanted to change.

\subsubsection{The rural lab as a compromise between CSR managers' desires and their perception of marketing representation}

For Paul and Charlotte, the rural lab was a project aimed first and foremost at including impoverished West African populations within the scope of Firm H's consumers and at developing specific telecom products that would improve their living conditions. Both Charlotte and Paul believed that Firm $\mathrm{H}$ had a technological expertise which, if used diligently, could help to improve the daily life of rural West African populations. In October 2011, Charlotte returned to Mali for a field trip to meet West African actors with a view to assessing more specifically how the rural lab could be developed in a West African business unit. She visited several rural projects run by different development agencies. These visits were an opportunity to speak to villagers about their living conditions. Later, based on the information collected, Charlotte and Paul worked out examples of telecommunications services that could be developed by Firm $\mathrm{H}$ to meet the needs of West African villagers, as summarized in figure 2.

$$
<<\text { Insert Figure } 2 \text { about here }>>
$$

This list of potential services and products was included in a PowerPoint presentation summarizing Charlotte's Malian field trip and suggesting that Firm H begin by developing a small 
Research of Development unit to better understand the needs and habits of rural populations before developing suitable technological solutions. It was therefore an initial formalization of the project. Charlotte and Paul framed the rural lab as a channel enabling the collection of material for the purpose of developing technological solutions. They offered an account that mimicked the DNA of Firm $\mathrm{H}$ and embodied the technological cluster of Firm $\mathrm{H}$ representations. In conjunction with this general cluster, the project also reflected Charlotte and Paul's vision of what Firm H should be doing - that is, to put its technological expertise at the service of improving the living conditions of rural populations.

However, while for both Charlotte and Paul societal aims prevailed over business aims, they knew this was not the case for marketing audiences. Even though the culture in the marketing department was very technologically-oriented and therefore corresponded well with Charlotte and Paul's proposal, the poverty of the populations targeted by the rural lab would be a challenge for corporate marketing ${ }^{15}$. Yet the first presentation contained no information showing that either the rural lab or downstream products would be profitable. Neither did the presentation show how the rural lab could be initially financed and maintained. At the same time, the CSR department had neither its own budget to start the project on its own nor the legitimacy to convince any business unit to embark on the project and develop it locally. It was therefore important that the marketing department support the rural lab. As a result, in their framing of the rural lab, Charlotte and Paul sought to emphasize the financial cluster of the ideal representation in the firm as well.

During the winter of 2011-2012, Charlotte and Paul developed a new presentation specifically devoted to the rural lab business plan. While developing the presentation Charlotte and Paul were mindful of the fact that because Firm $\mathrm{H}$ was already selling SIM cards and telecommunication minutes to rural African populations, from the standpoint of its marketing department, the firm was already making a positive contribution to the living conditions of local populations and nothing more 'developmental' was needed. The field notes below show how Richard articulated this view:

Richard explained that it is very difficult to convince the corporate marketing director for Africa and the Middle East because for him selling telecommunication minutes through scratch cards already contributes to the development of West African territories. He doesn't understand why Firm H should develop products that are not highly profitable for a market they already have. (From the field researcher's logbook, April $5^{\text {th }}, 2012$ )

15 It is not clear if any corporate marketers directly expressed a concern for a lack of solvency or if this is a point that Charlotte and Paul had internalized. 
As a result, in framing the rural lab in a manner that would be palatable to the marketers of Firm H, Charlotte and Paul excluded traditional CSR business case arguments according to which developing products for impoverished populations can help increase consumer numbers or construct a positive image for the firm and thereby enhance bottom-line performance (Prahalad and Hammond 2002; Porter and Kramer 2011). Their presentation concentrated only on aspects that would show how the rural lab could directly contribute to Firm H's bottom line. In other words they chose to frame their argument according to a Profit Realization discourse, instead of Share Value or Base of the Pyramid discourses.

To show that the rural lab was profitable, it was first important to demonstrate that despite the poverty of its target populations, the rural lab would attract profitable clients. That is, although the project was to collect information on rural West African populations for use by Firm H's corporate marketing department and African business units in developing their own products, the information would also be sold to NGOs, governments, institutional agencies and other companies that needed the information to develop programs or business solutions for these populations. The rural lab was therefore modeled on internet companies such as Facebook, Google and Pinterest that exchanged free services (e.g. connection between people, efficient information searching on the internet, information collection through images) for information about users, which would later be sold to different organizations for different purposes (marketing, institutional statistics, etc.). These organizational consumers are identified in the bottom left of figure 3:

$$
<<\text { Insert Figure } 3 \text { about here }>>
$$

Because these target customers were well-established organizations, they represented financially reliable clients and a potentially robust revenue stream. This source of revenue was therefore presented as a safeguard against the poor rural West African populations for whom the downstream products would later be developed. Therefore, Paul and Charlotte's strategy was to shift the target consumer from impoverished populations to a more reliable and solvent consumer group. This made it possible to demonstrate that the project could be profitable while attending to the needs of impoverished populations. However, for Paul and Charlotte, developing a profitable project that reproduced the financial cluster of the representation was a way of showing to colleagues that they understood the rules and norms at play within Firm H.

The ambition to achieve a profit was also visible in the financial business model included in the PowerPoint presentation since the aim of the project was not merely to break-even but to make a profit. 


$$
<<\text { Insert Figure } 4 \text { about here }>>>^{16}
$$

However, as shown by such citations of the financial cluster of the representation, the notion of profit maximization was dropped in favor of profit-making. The financial business model therefore represented an extensive reinterpretation of the financial cluster of the representation. However, the proposal was more traditional than what Charlotte at least would have wished for - in other words, that covering costs would have been sufficient to provide 'services to clients and nourishing its ecosystem' (Charlotte, interview, February 2016). However, to progress with her vision, Charlotte also knew that she had to present a project that achieved the financial cluster embodied within the Firm $\mathrm{H}$ representation. The PowerPoint presentation was therefore framed on the basis of Charlotte's usual strategy - that is, to perform the business discipline through the formulation of a profitable project and to eventually exercise a degree of agency in working with impoverished West African populations. The proposal inverted the CSR business case discourse in which social concerns can be exploited to meet the firm's economic objectives. Instead, Charlotte exploited the economic to satisfy the needs of the social. It also satisfied Paul's desire to work for what he perceived to be the interests of rural populations.

Nevertheless, convincing marketing that the rural lab could be profitable by bringing more solvent clients was not only a strategy to make the project acceptable to corporate marketers in order to develop it; it was also a strategy designed to ensure the department would start working with impoverished West African populations and eventually shift marketing practices. Therefore, it was a strategy designed to incrementally change existing approaches to product and service development focused on developing technological solutions responding to the problems of high-income populations. This reinterpretation was also central to Charlotte's role at Firm $\mathrm{H}$ since the inclusion of the most vulnerable was linked to her mandate to conduct stakeholder dialogues. As the logbook extracts below show, in Charlotte's view, in order to address low-income populations sustainably, the company needed to rethink how it defines consumers:

Charlotte again mentions the meeting about the project for the rural lab. [...] She talked about the fact that people outside the CSR department think 'client', while the goal of the project is to grasp people's needs and develop solutions [to meet these needs] through telephones. (From the field researcher's logbook, September 13" th 2011 )

\footnotetext{
16 The reader may have noticed a philanthropic phase to fund the early stage of the project. However, while Paul and Charlotte thought that the marketing department might fund the initial phase, the department was rather reluctant to commit money to projects targeting poor populations. Therefore, it was decided that Charlotte and Paul would apply for funding from business-oriented foundations such as the Bill \& Melinda Gates Foundation, which has been keen to fund business projects targeting the poor.
} 
Thus, Charlotte explained that her marketing colleagues were tempted to frame any new customer in terms of their purchasing power, which de facto excluded impoverished populations. It was therefore necessary to approach the rural consumer, not in terms of purchasing power and solvency, but in terms of needs. Such an approach therefore placed social goals up front and client solvency in the background. The rural lab thus sought to reconstruct customer relations through a more inclusive and less financially aggressive vision of customers. This reconstruction challenged the core representation within Firm $\mathrm{H}$ by suggesting a softening of the financial element within it.

A specific element illustrates this softening of the financial cluster of the representation: the reinterpretation of the financial figure. In Firm H, projects were expected to be profitable within 18 months in the case of any regular product and between 2 and 3 years maximum in the case of projects deemed highly innovative. This is shown in the PowerPoint presentation ${ }^{17}$ setting out the general product launch process in Firm H:

$$
<<\text { Insert Figure } 5 \text { about here }>>
$$

However, the bullet point 'long ROI ( $>3$ years)' corresponding to the payback period ${ }^{18}$ on Figure 4 points to the fact that the payback period within the rural lab was longer than what was normally expected in Firm $\mathrm{H}$. For Charlotte, the reinterpretation of the accounting figure was primarily to transform marketing practices and therefore properly address the needs of rural populations. At the same time, citing the appropriate financial vocabulary was decisive in convincing marketers that the rural lab was a business project. Her strategy was therefore to frame the rural lab through a discourse that extensively cited accounting figures and presented them at the center of any discourse addressing the marketing department.

This story around $\mathrm{ROI}^{19}$, it was about opening the marketing door, and this is what was important. Because even if it only enabled us to talk with people from marketing; otherwise what was the point [of the ROI]; [...] [and talking with marketing] was actually fundamental. (Charlotte, interview, February 2016)

Through these citations of financial discourse, Charlotte assumed that the rural lab would be identified as a project that meets the characteristics of Firm H's representation and would therefore be accepted by marketers. This would eventually enable incremental change, allowing a longer

\footnotetext{
17 This PowerPoint presentation was initially in English. No translation adjustment was therefore undertaken.

18 Both marketing department employees and Charlotte used the English term 'ROI', referring to the time needed to obtain a return on investment), for what is referred to in accounting as the payback period (in French, délais de rentabilisation ou période d'amortissement).

${ }^{19}$ Idem
} 
payback period and eventually including impoverished populations in the customer population of Firm H.

\subsubsection{CSR subjection through discipline and desire}

The quotation of accounting figures was a strategy deployed by Charlotte and Paul not only to sell the rural lab to the marketing department but also to perform themselves as managers iterating the representation of the ideal employee. These performative iterations enabled Paul and Charlotte to present themselves as respectable peers familiar with the Firm's vocabulary and its main aims and able to develop actions directed towards those aims. In other words, these performances enabled Paul and Charlotte to show that despite working for the CSR department they behaved according to the same representation as their colleagues from the marketing department.

However, citing financial discourse to frame the project was only in part a conscious strategy aimed at gaining legitimacy for themselves and the CSR department in Firm H. Charlotte admits:

I think there is, how can I put it, an automatic reflex, you know. We've internalized demands. I think that even before I am asked, spontaneously, I try to answer with [accounting] numbers (Final interview with Charlotte, February 2016)

Thus, Charlotte had internalized Firm H's financial discipline and mechanically cited accounting figures to perform in accordance with the representation of the employees working for Firm H. In other words, she had subjectivized herself as a manager reproducing financial expectations. Despite her discourse of rebelliousness, she was not able to escape the dominant norms embodied within the representation.

Nevertheless, at the same time her interest in the social dimension of the project often resulted in her momentarily overlooking the need to iterate the financial component of the representation. Thus, if she presented the project in front of a marketing audience receptive to the societal dimension of the rural lab, she would focus less on its financial metrics. These interactions provided an opening for her to redefine consumer relationships and better integrate impoverished populations within the scope of what was understood to be the Firm $\mathrm{H}$ client. In her various interactions with different marketing groups, Charlotte would attempt to balance the social and the financial and, swept up in her enthusiasm, would sometimes forget about the importance of mimicking the financial cluster of the representation. The following recalls Charlotte's experiences after meeting different marketing groups on two successive days:

I remember having seen Charlotte a day after one of her presentations on the rural lab to the strategic marketing team. She was happy because she told me they liked the project and seemed to understand its social dimension. The next day, I met again with Charlotte 
after a meeting with marketing employees responsible for technical development. She had lost her enthusiasm. She told me that the meeting was tough because she acted like a fool by talking too much about the social impact and not concentrating on the accounting figures. She told me she has to follow the rules better, because after all her job was not just about the social [impact]. (Memories written in the reflexive logbook after the end of the fieldwork period, March 16 $\left.6^{\text {th }}, 2013\right)$.

By iterating a version that strayed too far from the representation of the ideal Firm $\mathrm{H}$ employee, Charlotte became aware that she had lost some credibility in front of this second audience. Her conclusion - that in future she must be careful to stay within the business case framework when presenting the rural lab - illustrates how the judgement of others foreclosed Charlotte's personal desire, thus bringing her back within Firm H's expectations. Charlotte thus reminded herself to perform herself through a more disciplined version of the representation, which she rationalized as being required to achieve her own goals.

As a result, throughout the development of the rural lab, Charlotte sought to find the right balance between various tensions that were intertwined with each other. One of these was the tension between her reinterpretation of the representation and her colleagues' perception of her performative behavior. Another such tension was her internal tension marked by her desire to work for what she perceived as the needs of West African populations and the disciplinary performative iterations exercised by herself on herself. However, she constantly adjusted her performative production of the representation because of her desire to work for West African populations but also because of her desire to be accepted as a Firm $\mathrm{H}$ employee. The following illustrates these intertwined tensions

It seems that, for us, the ROI [in English, for payback period] ${ }^{20}$ couldn't be the same as [for regular business products] [...]. But let's not fool ourselves - this goes to the heart of the company. The heart of the company is to produce products that get a return on investment. As for the time in which we can expect a return on investment, that's another story $[\ldots]$ but the rule of a private company, which is fair, is that my investment brings in some money at some point. (Charlotte, interview, February 2016)

In the above, Charlotte first locates herself as an agent of the company, embodying the dominant discourse and performing herself according to the representation; but then and only then, she offers an alternative way to formulate the financial discourse, only to be caught up again in the discipline of this discourse. In other words, Charlotte constantly produced and secured her own self

\footnotetext{
20 Idem
} 
from expectations ${ }^{21}$ compelling her to follow the financial representation, but also from her desire to distance herself from this very representation.

Similar tensions were apparent in Paul's behavior. For instance, the following abstract presents a discussion between Paul, Charlotte and the researcher around qualitative data on rural household consumption and financial management. The data had been brought by the researcher from one of her Malian missions. Charlotte was arguing for the information to be used to convince marketing that this population was worthy of study through the rural lab.

It seems that Paul doesn't understand what I try to explain. I give him an example. He repeats that he doesn't understand what I'm talking about because I need to be factual. I eventually go to draw a graphic representation on the board. Paul goes back to his chair. The discussion is tense. He says: "We need facts and objectivity to relay the message to other managers. We need to answer demands about marketing and distribution aspects.”[...] (From the field researcher's logbook, 09 December 2011, Firm H)

Paul appeared upset because in his view the information and therefore the message was not clear since it was neither "factual" nor "objective" and therefore not crafted to properly address the marketing audience. Put differently, for Paul the discourse provided by the researcher and supported by Charlotte failed to sufficiently iterate the representation. Therefore, he argued for a reframing of the discourse to align it more closely with what he perceived to be the discursive expectations of marketing. He was therefore highlighting the importance of a disciplinary reproduction of the financial discourse to mimic the language of marketing. In this extract, he performs himself as a disciplined representative of a strict version of the ideal CSR employee and demands that the researcher and Charlotte perform the representation at play in Firm H more strictly.

However, a few minutes after the conversation in which Paul called for factual and objective figures, Charlotte decided to take a look at the PowerPoint presentation created to present the information from the researcher's field trip.

Then we look at the presentation. Paul, who has started to tidy up his stuff, comes back to the table. It's time for him to leave because it's $6 \mathrm{pm}$. But apparently the content of the slides is interesting enough to make him stay. [...]. But slowly, in the course of the conversation [...] [Paul] says more and more frequently that it's okay if we don't have numbers. (From the field researcher's logbook, 09 Dec 2011, Firm H)

By following his own interests, Paul began to distance himself from the need to cite numbers. Although, because of his 'good student' nature, he was more sensitive to organizational discipline than Charlotte, like her, he could be caught up by his own desire to work with the rural populations.

\footnotetext{
${ }^{21}$ Her own and other expectations, knowing that her own expectations were also the result of the internalisation of other expectations.
} 
He was able to momentarily distance himself from the strict necessity to closely mimic the representation to perform himself according to the norms governing the behavior of the ideal employee. Thus, Paul, like Charlotte, was occasionally swept up by his desire to pursue the social aims of the rural project. He also often ended up being caught in the discipline of the representation and foreclosed himself after having shown too much interest in the rural population and not enough interest in profitability. Like Charlotte, Paul always had to secure his own production of the self from the judgements of others. Like Charlotte, the production of his own self was performed through strict iterations of the discipline inscribed in the representation of the ideal employees working for Firm $\mathrm{H}$, which he had internalized, and his desire to work with rural West African populations.

\subsubsection{Incremental change}

Paul and Charlotte's different performative iterations helped both of them to define a project, which comprised, on the one hand, Paul's disciplined vision, closely mimicking the Firm $\mathrm{H}$ representation and therefore what he perceived to be the expectations of marketing employees, securing the chance to make the project acceptable, but also, on the other hand, Charlotte's transformative vision of CSR.

The rural lab is a hybrid, between what I wanted to do and what Charlotte wanted to do. I wanted something that was completely integrated with the marketing department. And Charlotte was saying: 'they're not ready. [...] They won't agree to let us develop the project, so it's better we develop the project on our own $[. .$.$] and when they come to see$ that it's of interest, they'll wake up.' I didn't want to do this. (Paul, final interview, June 2012)

Overall, Paul was keener to work within the business framework than Charlotte but, at the same time, working with Charlotte made Paul move away from the representation of the ideal Firm $\mathrm{H}$ employee to develop what he called a hybrid project integrating novel aspects such as the needs of rural West African populations. The project thus embodied a relatively innovative vision of the representation that Paul had accepted and was advocating to his marketing colleagues. As a result, Paul himself iterated the representation slightly less closely that he might have if Charlotte had not been involved. Therefore, Charlotte incrementally shifted Paul's performative iterations and therefore his subjection, extending more broadly the possibility of subjection through the extension of the representation and eventually the representation itself. On the other hand, Paul attempted to foreclose Charlotte in an attempt to reduce the risk that marketing employees would reject the project if Charlotte were to present the rural lab in terms that were not acceptable to them. 
Paul was not the only person to experience an incremental shift. At the end of the data collection process, Paul and Charlotte had received sufficient support to begin the development of the rural lab in collaboration with the Côte d'Ivoire business unit, implying that corporate marketing was to some extent convinced of the relevance of the project.

Right now, I'm working with the Côte d'Ivoire business unit and the Marketing Director told me [regarding the rural lab], 'This sounds great...', [...] and when I told her that with Charlotte: 'We'll go and meet other institutions, we'll see who we can work with [in the field, for example with local NGOs] [...] This is collaborative work'. She told me, 'oh cool, this is a project that seems to have been well thought out'. (Paul, interview, June 2012)

Although, as the above suggests, Charlotte and Paul may have succeeded in making the rural lab an acceptable project within Firm $\mathrm{H}$, the rural lab was never developed. This is because, in early 2013, Paul was transferred to another position ${ }^{22}$ within the firm and six months later Charlotte followed her husband who took a job in another country. For reasons that remain unclear, no other CSR managers took up the project. Nevertheless, the process of selling the idea of the rural lab served to transform the perception of low-income rural populations within Firm $\mathrm{H}$ and therefore incrementally remodeled consumer relationships in corporate marketing. A new customer segmentation was specifically defined for people living on less than $€ 20$ per month, for which specific products would be developed. This segmentation was established in accordance with their degree of rurality ${ }^{23}$ and included four categories of customers split between marketing and CSR departments. The CSR department was charged with handling the two poorest and more rural customers and a small budget was specifically assigned for the development of projects targeting those populations, for which they could eventually decide the length of the payback period. Programs such as smartphone applications for rural farmers in Mali and Niger transmitting weather forecasts were eventually developed. Marketing practices relating to West African populations within corporate marketing were also slightly moving toward more inclusive services attending to the needs of populations.

We have to be smart [...] this is about bringing services that bring something [to the local population]. For example, we have an idea to develop services that address the community $[\ldots]$ and not the individual, the village's Chief $[\ldots]$ to give him the means to better communicate with his community. (Corporate senior marketer for Africa and the Middle East, interview, June 2012)

22 In Firm H, executives were supposed to change position every three years. However, Paul had worked for the CSR department for five years at least.

${ }^{23}$ Even within the group, financial disparities were observed. In most cases, the more rural the individual, the poorer she was. 
Moreover, CSR managers seemed to have become valuable collaborators, at least from the perspective of the corporate marketer in charge of the new customer segment:

There aren't exactly the same needs in rural areas. When we look at rural incomers, we talk a lot with Charlotte, where it's not about creating expensive value, but keeping low prices, creating values corresponding to needs. (Corporate junior marketer responsible for customer segmentation in Africa and the Middle East, interview, June 2012)

Through their iterative performances of the rural lab, Charlotte and Paul seem to have encouraged changes in key elements within Firm $\mathrm{H}$, such as consumer relationships within corporate marketing, the perception of CSR managers by corporate marketers and the perceived viability of projects targeting impoverished populations. Nevertheless, even though the CSR department was given a small budget ${ }^{24}$ to pursue its own project, all other projects would be developed following the Firm $\mathrm{H}$ rule of the 18-month payback period. The changes within the representation were therefore extremely incremental, not disturbing the CSR business case discourse as such.

\section{Discussion}

This paper focused on performative iterations of two CSR managers attempting to reform business practices and discourses governing their subjection in order to align their work more closely with their desires. Any employee is governed by a general representation of identity defining an ideal expected behavior. In order to be recognized as belonging to the firm, an employee disciplines herself and mimics the cluster of representations prevailing within the firm. Over time, employees internalize the discipline of this process. However, subjection is never the full effect of discipline. Subjection also encompasses the desires of subjects (Butler 1988, 1990, 1993, 1997b, 1997a, 2004). Therefore, an employee subjectivizes herself through the constant attempt to reconcile tensions between disciplinary reproduction of the dominant representation and her own desire, eventually creating spaces for change within the representation. We showed that the two CSR employees did not escape this process. They framed the CSR project, which they developed in accordance with the clusters of this representation embodying the dominant financial discourse and, ultimately, the CSR business case discourse. Thus, in undertaking CSR activities, CSR managers discipline themselves in accordance with the dominant financial discourse. Nonetheless, because they consider that business practices should evolve to better serve the interests of impoverished populations, they reinterpret the representation rather differently. Therefore, they also discipline themselves in accordance with their

\footnotetext{
${ }^{24}$ It was described as 'small' by Charlotte. No figure was provided to quantify the amount of the budget.
} 
desires, creating spaces to perform the dominant CSR business case discourse differently and exercise an incremental degree of agency. For instance, the CSR managers observed in this study, while framing their project in terms of payback periods, sought to integrate novel aspects within CSR practices by introducing products and services for the most impoverished rural populations. On a more fundamental level, they sought to shift the habits of the organization away from focusing on purchasing power as a criterion for developing certain types of business projects to an approach focusing on the needs of populations, which required extending the length of the payback period. Such alternative iterative performances, if they become acceptable, would serve, in our view, to extend the range of possibilities for framing CSR programs and, by extension, the range of practices that can be performed within the organization, ultimately incrementally extending the representation governing employee subjection.

Among other things, our study therefore highlights 1) the capacity of the subject constructed through power to act on the controlling discourse that governs their subjection and 2) the positionality of the CSR manager between the two traditional entities of the CSR literature, namely top management and the suffering others. In the following section, we examine each of these themes in turn.

\subsection{Transforming the controlling discourse incrementally through performative iterations}

By studying disciplinary mechanisms, the accounting literature takes as its starting-point that the neoliberal form of governance is distinguished by working though the agency and capacities of the governed to realize their objectives (Lambert and Pezet 2011; Miller and O'Leary 1994; Cooper 2015). As Lambert and Pezet (2011) show, individuals use this capacity for agency to discipline themselves even more intensely in order to meet organizational expectations. Thus, it is argued that agency is in fact a fake promise that serves to reinforce disciplinary mechanisms, with both operating as a deadly embrace (Zizek 1999) to always produce a more disciplined subject. Studies focusing on the disciplinary mechanisms of subjection do not examine attempts to influence or modify these disciplinary mechanisms to enable alternative forms of subjection. However, Butler (1988, 1990, 1993, 1997b, 1997a, 2004, 2005) provides an understanding of how individuals subjectivize themselves through performative iterations of the representation of the ideal subject and extend this representation through their own desires. 
Therefore, we demonstrated that while managers subjectivize themselves through the disciplinary reproduction of the controlling discourse, this reproduction also enables them to propose relatively novel forms of organizational practices. These innovative discursive forms of organizational practices show that there are alternative ways of doing one's job that ultimately serve to incrementally extend the controlling discourse and create spaces for slightly alternative forms of subjection, until foreclosure occurs.

More specifically, we show that incremental change operates through performative iterations enacted through repetitive citations of accounting and financial rhetoric used to frame CSR projects, showing therefore that financial discourses dominate employee subjection. Thus, these citations are used by the person who reproduces the expected discipline on herself to become a subject of the firm. However, some of the citations she offered are extensive reinterpretations of accounting and financial discourse, which enables the introduction of new elements within the discourse, thereby transforming practices. It produces a version of the representation that appears to be similar to the representation but at the same time slightly different. Likewise, the CSR employee, by using this specific financial vocabulary, presents herself as a subject of the firm. However, the twisted vocabulary enables her to offer a rather personal and innovative account of the representation of the ideal employee. Thus, these somewhat novel organizational practices, performed through the discourse of subjection, are marginally different from those that would have emerged from a stricter reproduction of the representation, eventually extending this representation. Nevertheless, the process of foreclosure means that change remains marginal. In our case, the centrality of the business case within the CSR discourse is not supplanted by another discourse; and the dominance of the profit-oriented organization persists, though in slightly nuanced alternative versions. Therefore, our results reveal not a refusal to be governed by the CSR business case discourse, but every CSR manager's desire to be governed differently - that is, through a reinterpretation of the representation that is more closely aligned with their own personal vision. We therefore show that while the process of discipline is never total, the process of agency is also incomplete.

Moreover, our results show explicitly that the production of these alternative forms of subjection, which eventually enable incremental change, is not a linear process. Rather, it is realized through a series of endless tensions that the subject constantly experiments with and attempts to reconcile in order to construct and endlessly secure her own self. These tensions encapsulate, on the one hand, the desire to be recognized as an employee, which implies a more or less disciplined reproduction of the representation of the ideal employee, and, on the other, the desire to act 
according to one's own personal and ethical beliefs. Yet, the desire to be recognized as an employee itself encapsulates the tension coming from the various discourses embedded within the representation of the ideal CSR employee and with which the CSR employee subjectivizes herself as an acceptable employee. However, these discourses are available at different degrees depending on the global firm context or on the audience addressed by the CSR employee, pushing her to constantly adapt her narrative. Through subjection, the CSR employee experiences and manages the contradictions of the CSR business case discourse and learns how much and how little her CSR identity can in fact allow her to achieve.

We acknowledge that several factors coalesce in our case to enable performative agency and render the incremental transformation of the controlling discourse far less challenging than in other contexts. The first factor is the nature and history of the organization itself. As the case suggested, a public service orientation was to some extent sedimented in Firm H's culture. Organizational actors might therefore have been keener to allow a shift in the reframing of consumers from the standpoint of solvency to one in terms of needs. As a result, extensions of the CSR discourse toward a more inclusive definition of consumer groups might have been far less fraught in our case that in the case of an organization with an unbroken history of private ownership and for which profit maximization was the only main narrative through which employees subjectivized themselves for decades. The second factor is the position of the employee in the organization's hierarchy and their particular organizational circumstances. Our CSR managers were not directly threatened by the possibility of becoming unemployed, as was the case of the Caterpillar workers studied by Miller and O'Leary (1994). Nor were they positioned as closely to the goal of profit maximization as the management accountants studied by Lambert and Pezet (2011). They had secure jobs and their mandates were about creating innovative societal programs. Therefore, they were called upon to develop new ideas, even though these new ideas had to strictly embody the firm's representation. As such, they enjoyed a broader space to reformulate the dominant discourse and incrementally transform it than the actors studied by Miller and O'Leary (1994) or by Lambert and Pezet (2011). Related to this is the biography and organizational history of the employees themselves. Charlotte's attempts to transform the organization were most likely grounded in the training that she had received during her postgraduate studies. In addition, the support of her line manager to 'mess up the organization's habits' reinforced her beliefs and her capacity to act. Her more radical position and actions stand in contrast to those of Paul, who was equipped with a different set of life and organizational histories. Charlotte therefore appeared much more resourceful than Paul. These resources, operating as a form 
of empowerment, had undoubtedly bolstered her ability to stand up for what she believes in and to reformulate the representation.

\subsection{The CSR manager: a subject positioned in between organizational hierarchy and civil society}

Our case suggests that agency may emerge from the disciplined subject and her discretionary reinterpretation of the complex web of controlling discourses. In particular, our case indicates that incremental change to a specific representation that occurs at the level of the individual might arise from a space opened at the intersection of conflicting representations enabling a degree of selfformation. This points to the role of other representations to fuel agency and so enable incremental actions upon other controlling frames, thus lending support to a focus on multiple accountabilities in the accounting literature (Arrington and Francis 1993; Schweiker 1993; Messner 2009; Sinclair 1995). In this regard, CSR managers stand in a unique position. As employees, not only are they confronted with and accountable to the controlling discourse of the business case, but through their own personal desires, networks within the sustainability community and intimate contacts with stakeholders (such as impoverished communities) they are also exposed to alternative discourses regarding the organization's accountability to society. The CSR managers examined in our study were therefore shown to be torn between the organization's normative expectations focused on profit maximization and their perceptions of the needs of impoverished rural villagers. Thus, they stand between the traditional duo of actors studied in social and environmental accounting research: the

organization and stakeholders or, as Roberts (2003) puts it, "the top managers and the suffering others". It is thus possible to conceive of CSR managers as the link between these two classical entities managing the tension between what is presented to them as being in the interests of the firm (doing well) and what they perceive as being the interests of impoverished populations (doing good). However, the CSR accounting literature has not taken advantage of this unique position of the CSR manager and the potential insight that a study of their actions could bring to the literature.

We showed that while CSR managers perform the dominant financial discourse to subjectivize themselves, they also attempt to bridge the interests of the firm's order with the interests of some stakeholders. Through such a reformulation, they attempt to convince their colleagues of the necessity to take into consideration the latter's needs. By strategically using the rhetoric of profit, they are able to create a space for framing CSR projects in a way that is more aligned with their perception of the needs of impoverished populations and incrementally transform organizational 
practices to make them more inclusive. By incremetally shifting the dominant discourse governing their subjection, they also incrementally participate in reformulating a sligthly different CSR business case discourse - one that is more inclusive of stakeholders. By studying these actors, this paper therefore demonstrates the complexity of the accountability relationship between an organization and its stakeholders beyond the traditional binary representation of the actors. In particular, we show that although CSR employees are expected to work solely in the interests of the firm, their desire to help stakeholders make them momentarily cross the line drawn by the traditional CSR boundary in such a way that, in the eyes of their colleagues, they end up representing the interests of stakeholders more than they do the interests of the firm. Therefore, our case demonstrates that the established boundary between what is external to the firm and what is internal to it can be porous because of the performative actions of actors. Our case also shows that the performance that leads CSR managers to momentarily position themselves on the side of stakeholders differs from one CSR subject to another on account of their social, psychological and historical trajectories. However, the relational dynamic between the different CSR managers renders this traditional boundary even more porous by encouraging the more 'naturally' disciplined subjects to distance themselves from the organizational hierarchy before everyone is reminded by foreclosure that they are supposed to work for the organization and therefore momentarily re-establish the traditional duo of actors.

Nevertheless, the conclusion of the case according to which incremental change succeeds in terms of including a broader set of demands emerging from broader populations but not in terms of financial expectations limits the positive account of the actions of the CSR managers. The rather optimistic tone of this study is partly explained by the fact that we focused more on the possibility of incremental change than on the effects of foreclosure. Focusing on the effects of foreclosure would instead reveal the sources and nature of the constraints which CSR managers face in their daily work and provide alternative insights into how CSR managers cope with these constraints, whether it be by adopting an illusionary posture of resistance (Fleming and Spicer 2003), engaging in organizational hypocrisy (Brunsson 1993) or through decoupling (Meyer and Rowan 1977). Moreover, the possibility of bringing incremental change within the organization is operated by two Western white upper middle class French managers wanting to construct projects for the West African populations they identified as being vulnerable. These populations do not speak for themselves. Their voices remain trapped in a discourse produced by these CSR managers, reflecting to some extent postcolonial, race and class domination. As a result, the original voices of West African populations do not penetrate the organization. Thus, if, from the organization's point of view, CSR managers 
appear to be challenging the traditional CSR boundary between the organization and stakeholders, thereby making it porus, this boundary remains impermeable for some external stakeholder groups.

\section{Conclusion:}

This paper was inspired by our interest in understanding the possibility of agency through subjection within an organization dominated by financial discourse in the context of CSR. It was particularly motivated by a desire to understand the possibility of altering the current neoliberal norms produced and reproduced by the performative iterations of financial discourses, whilst the accounting literature on subjection sees agency as fueling the discipline enabling any subject to better construct herself as an entrepreneur of the self (Cooper 2015). Therefore, this paper established that if the subject is a product of the discipline of financial discourse, she also exercises a degree of agency in participating in the production of herself, creating a space to think about agency and incremental change in the accounting literature on subjection.

Thus, using Butler, this study attempted to understand the possibility of agency of the CSR manager, described as being governed and subjectivized by the disciplinary discourse of the business case embodying the capitalist ideology. Nevertheless, CSR, which by nature embodies different interests and forms of accountabilities, appears to be an appropriate context for reinterpreting the dominant discourse and, therefore, incremental change. It would be of interest to study this

phenomenon in other business contexts where the presure for financial conformity is likely to be more intense in order to establish the extent to which performing business practices can alter dominant norms and therefore contribute to extending the financial discourse and related mechanisms.

Moreover, Butler provides a means of grasping the different tensions coming from different actors involved in the production of the capitalist discourse shaping and re-shaping the subject and, through it, incrementally transforming this discourse. Her theory is a powerful tool for understanding the variability and heterogeneous production of such a discourse by emphasizing that each actor contributes to extending it. It therefore allows for the study of the potential of each actor, though caught in this discourse of power, to challenge the dominant capitalist discourse through the formulation of what Boltanski (2011) calls critiques - that is, the capacity of any actor to conscientiously stand up against what she believes to be unfair. However, we showed that each of these critiques is formulated from a desire offering a unique version of the dominant discourse, 
which itself offers a unique extension of this dominant discourse governing subjection. It therefore disrupts the homogenic and unified nature of capitalism by showing the multiplicity of voices that participate in its production and its reproduction into different forms (Boltanski and Chiapello 1999). However, employee critiques directly related to financial discourse and involving accounting rhetoric still remain understudied. Therefore, based on the findings of this study, this may be an area worth exploring in the future.

Finally, we found that even if CSR managers succeed in incrementally transforming CSR practices in a manner that is more aligned with what they perceive to be the needs of voiceless stakeholders, these more inclusive transformations remain controlled by the dominant financial discourse of the firm, reinforcing the CSR business case discourse. Thus, rather than performing a radical transformation, such action runs the risk of extending the dominant hegemonic system by bolstering the image of a so-called benevolent organization (Boltanski and Chiapello 1999, Spence 2007, Spence 2009). Moreover, even though some CSR programs might successfully improve the living conditions of a few among impoverished populations, such success might set the stage for a further dismantling of the state and governmental disengagement, with corporations presenting themselves as substitutes for public entities, particularly in parts of the world where governments are perceived as being particularly weak and corrupt. In this view, then, CSR managers can be seen to actively participate in the long-term dissemination of the neoliberal ideology promoting markets and competition as the best way to organize society (Brown 2015). Meanwhile, Base of the Pyramid programs, whatever their format and respect for the needs of impoverished populations, maintain a perception of the poor as consumers since services must always be exchanged for money, constructing a dependency relationship between rural consumers and the capitalistic system (Alawattage et al. 2019). Moreover, those who are too poor remain excluded from the social body and are denied the fundamental rights accorded to any citizen, chief among them being the right to belong. As a consequence, following Spence (2007), it can be argued that whilst CSR managers might be able to articulate a certain critique at the level of practice, they are unable to do so at the more macro level - that is, against the capitalist structure. Therefore, this highlights the limits of possible change when acting from within capitalist organizations. Future studies should therefore consider more radical actions emanating from civil society and, in particular, if and how such groups mobilize financial rhetoric to drive change while addressing capitalist actors. 


\section{References}

Adams, C., and G. Whelan. 2009. Conceptualising future change in corporate sustainability reporting. Accounting, Auditing \& Accountability Journal 22 (1):118-143.

Adams, C. A. 2004. The ethical, social and environmental reporting-performance portrayal gap. Accounting, Auditing \& Accountability Journal 17 (5):731-757.

Alawattage, C., and S. Fernando. 2017. Postcoloniality in corporate social and environmental accountability. Accounting, Organizations and Society 60:1-20.

Alawattage, C., C. Graham, and D. Wickramasinghe. 2019. Microaccountability and biopolitics: Microfinance in a Sri Lankan village. Accounting, Organizations and Society 72:38-60.

Alvesson, M., and K. Sköldberg. 2009. Reflexive methodology: New vistas for qualitative research: Sage.

Archel, P., J. Husillos, and C. Spence. 2011. The institutionalization of unaccountability: Loading the dice of Corporate Social Responsibility discourse. Accounting, Organizations and Society 36:327-343.

Arjaliès, D.-L., and J. Mundy. 2013. The use of management control systems to manage CSR strategy: A levers of control perspective. Management Accounting Research 24 (4):284-300.

Arrington, C. E., and J. R. Francis. 1993. Giving Economic Accounts: Accounting as cultural practice. Accounting, Organizations and Society 18 (2/3):107-124.

Baker, M., and J. Roberts. 2011. All in the Mind? Ethical Identity and the Allure of Corporate Responsibility. Journal of Business Ethics 101 (1):5-15.

Banerjee, S. 2003. Who Sustains Whose Development? Sustainable Development and the Reinvention of Nature. Organization Studies 24 (1):143-180.

Bebbington, J., and I. Thomson. 2013. Sustainable development, management and accounting: Boundary crossing. Management Accounting Research 24 (4):277-283.

Becker, H. 1998. Tricks of the Trade: How to Think about Your Research While You're Doing It. Chicago: Chicago University Press.

Boltanski. 2011. On Critique, A Sociology of Emancipation. Cambridge: Polity Press.

Boltanski, L., and E. Chiapello. 1999. Le nouvel esprit du capitalisme. Paris: Gallimard.

Borgerson, J. 2005. Judith Butler: On organizing subjectivities. The Sociological Review 53:63-79.

Bourdieu, P. 2001. Science de la science et réflexivité. Paris: Raison d'agir.

Brown, J. 2009. Democracy, sustainability and dialogic accounting technologies: Taking pluralism seriously. Critical Perspectives on Accounting 20 (3):313-342.

Brown, J., and J. Dillard. 2013a. Agonizing over engagement: SEA and the "death of environmentalism" debates. Critical Perspectives on Accounting 24 (1):1-18.

- - - 2013b. Critical accounting and communicative action: On the limits of consensual deliberation. Critical Perspectives on Accounting 24 (3):176-190.

Brown, J., and H. Tregidga. 2017. Re-politicizing social and environmental accounting through Rancière: On the value of dissensus. Accounting, Organizations and Society 61:1-21.

Brown, W. 2015. Undoing the Demos: Neoliberalism's Stealth Revolution. Brooklyn, New York: zone book.

Brunsson, N. 1993. Ideas and actions: Justification and hypocrisy as alternatives to control. Accounting, Organizations and Society 18 (6):489-506.

Butler, J. 1988. Performative Acts and Gender Constitution : An essay in Phenomenology and Feminist theory. Theater Journal 40 (4):519-531.

- - - 1990. Gender Trouble: Feminism and the Subversion of Identity. New York: Routledge Classics.

1993. Bodies that Matter. New York: Routledge.

1997a. Excitable Speech, a politics of the Performative New York City: Routledge. 
-——. 1997b. The Psychic Life of Power. Stanford, California: Standford University Press.

- - 2 2004. Undoing Gender. New York: Routledge.

- - . 2005. Giving an Account of Oneself. New York: Fordham University Press.

Cho, C. H., R. P. Guidry, A. M. Hageman, and D. M. Patten. 2012. Do actions seak louder than words? An Empirical investigation of corporate environmental reputation. Accounting, Organizations and Society 37:14-25.

Cho, C. H., R. Roberts, and D. Patten. 2010. The language of US corporate environmental disclosure. Accounting, Organizations and Society 35 (4):431-443.

Chrisafis, A. 2009. Wave of staff suicides at France Telecom. The Guardian.

Contrafatto, M., and J. Burns. 2013. Social and environmental accounting, organisational change and management accounting: A processual view. Management Accounting Research 24 (4):349365.

Cooper, C. 2015. Entrepreneurs of the self: The development of management control since 1976. Accounting, Organizations and Society 47:14-24.

Cooper, S. M., and D. L. Owen. 2007. Corporate social reporting and stakeholder accountability: The missing link. Accounting, Organizations and Society 32 (7-8):649-667.

Costas, J., and D. Kärreman. 2013. Conscience as control - managing employee through CSR. Organization 20 (3):394-415.

Fleming, P., and A. Spicer. 2003. Working at a Cynical Distance: Implication for Power, Subjectivity and Resistance. Organization 10 (1):157-179.

Foucault, M. 1975. Surveiller et punir: Naissance de la prison. edited by B. d. Histoires. Paris: Gallimard.

-——. 1984. Histoire de la sexualité II: L'usage des plaisirs. Paris: Gallimard.

——_. 2001. L'Herméneutique du sujet : Cours au collègue de France. 1981-1982. Paris: Gallimard.

-_- 2004a. Naissance de la biopolitique : Cours au collège de France (1978-1979) Paris: Seuil.

-_- 2004b. Sécurité, territoire, population : Cours au Collège de France (1977-1978). Paris: Seuil.

Girei, E. 2016. NGOs, Management and Development: Harnessing Counter-Hegemonic Possibilities. Organization Studies 37 (2):193-212.

Graham, C. 2010. Accounting and the construction of the retired person. Accounting, Organizations and Society 35:23 - 46.

Gray, R. 1992. Accounting and environmentalism: An exploration of the challenge of gently a accounting for accountability, transparency and sustainability. Accounting, Organizations and Society 17 (5):399-425.

- - - 2002. The social accounting project and Accounting Organizations and Society Privileging engagement, imaginings, new accountings and pragmatism over critique? Accounting, Organizations and Society 27 (7):687-708.

- - - 2010. Is accounting for sustainability actually accounting for sustainability... and how would we know? An exploration of narratives of organizations and the planet. Accounting, Organizations and Society 35:47-62.

Hopper, T., and N. Macintosh. 1993. Management accounting as disciplinary practice: the case of ITT under Harold Geneen. Management Accounting Research 4 (3):181-216.

Hoskin, K. W., and R. H. Macve. 1986. Accounting and the examination: A genealogy of disciplinary power. Accounting, Organizations and Society 11 (2):105-136.

- - 1 1988. The genesis of accountability: The West Point connections. Accounting, Organizations and Society 13 (1):37-73.

Jeacle, I. 2015. The diet of the nation: The state, family budgets and the 1930s nutritional crisis in Britain. Critical Perspectives on Accounting.

Jeacle, I., and E. J. Walsh. 2002. From moral evaluation to rationalization: accounting and the shifting technologies of credit. Accounting, Organizations and Society 27 (8):737-761. 
Jensen, M. 2002. Value Maximization, Stakeholder Theory, and the Corporate Objective Function. Business Ethics Quaterly 12 (2):235-256.

Laigle, F. 2016. France télécom : chronique d'une tragédie sociale. In Affaires sensibles. Paris: France Inter - Radio France, 3 to $4 \mathrm{pm}$.

Lambert, C., and E. Pezet. 2011. The making of the management accountant - Becoming the producer of truthful knowledge. Accounting, Organizations and Society 36 (1):10-30.

Malsch, B. 2013. Politicizing the expertise of the accounting industry in the realm of corporate social responsibility. Accounting, Organizations and Society 38 (2):149-168.

Margolis, J. D., and J. P. Walsh. 2001. People and Profits? The Search for a Link Between a Company's Social and Financial Performance: Psychology Press.

McKinlay, A. 2010. Performativity and the politics of identity: Putting Butler to work. Critical Perspectives in Accounting 21:232-242.

Messner, M. 2009. The limits of accountability. Accounting, Organizations and Society 34 (8):918938.

Meyer, J., and B. Rowan. 1977. Institutional Organizations: Formal Structure as Myth and Ceremony. American Journal of Sociology 83 (2):340-363.

Miller, P., and T. O'Leary. 1987. Accounting and the construction of the governable person. Accounting, Organizations and Society 12 (3):235-265.

- - . 1994. Accounting, "economic citizenship" and the spatial reordering of manufacture. Accounting, Organizations and Society 19 (1):15-43.

Milne, M. J., H. Tregidga, and S. Walton. 2009. Words not actions! The ideological role of sustainable development reporting. Accounting, Auditing \& Accountability Journal 22 (8):1211-1257.

Munro, I. 2014. Organizational Ethics and Foucault's 'Art of Living': Lessons from Social Movement Organizations. Organization Studies 35 (8):1127-1148.

Nadin, S., and C. Cassell. 2006. The use of a research diary as a tool for reflexive practice: some reflections from management research. Qualitative Research in Accounting \& Management 3 (3):208-217.

Neu, D., H. Warsame, and K. Pedwell. 1998. Managing public impressions: Environmental disclosures in annual reports. Accounting, Organizations and Society 23 (3):265-282.

O'Dwyer, B. 2002. Managerial perceptions of corporate social disclosure: An Irish story. Accounting, Auditing \& Accountability Journal 15 (3):406-436.

- - - 2003. Conceptions of corporate social responsibility: the nature of managerial capture. Accounting, Auditing \& Accountability Journal 16 (4):523-557.

O'Dwyer, B., D. L. Owen, and J. Unerman. 2011. Seeking legitimacy for new assurance forms: The case of assurance on sustainability reporting. Accounting, Organizations and Society 36 (1):31-52.

O'Dwyer, B., and J. Unerman. 2016. Fostering rigour in accounting for social sustainability. Accounting, Organizations and Society 49:32-40.

Porter, M., and M. Kramer. 2011. Creating Shared Value. Harvard Business Review 89 (1-2):62-77.

Prahalad, C. K., and A. Hammond. 2002. Serving the world's poor, profitability. Harvard Business Review (Sept):8.

Preston, A. M. 2006. Enabling, enacting and maintaining action at a distance: An historical case study of the role of accounts in the reduction of the Navajo herds. Accounting, Organizations and Society 31 (6):559-578.

Randall, J., and I. Munro. 2010. Foucault's Care of the Self: A Case from Mental Health Work. Organization Studies 31 (11):1485-1504.

Riach, K., N. Rumens, and M. Tyler. 2016. Towards a Butlerian methodology: Undoing organizational performativity through anti-narrative research. Human Relations 69 (11):2069-2089.

Roberts, J. 1991. The possibilities of accountability. Accounting, Organizations and Society 16 (4):355-368. 
- - - 2003. The Manufacture of Corporate Social Responsibility: Constructing Corporate Sensibility. Organization 10 (2):249-265.

- - - 2005. The Power of the 'Imaginary' in Disciplinary Processes. Organization 12 (5):619-642.

- - - 2009. No one is perfect: The limits of transparency and an ethic for 'intelligent' accountability. Accounting, Organizations and Society 34 (8):957-970.

Roberts, J., P. Sanderson, R. Barker, and J. Hendry. 2006. In the mirror of the market: The disciplinary effects of company/fund manager meetings. Accounting, Organizations and Society 31 (3):277-294.

Schweiker, W. 1993. Accounting for ourselves: Accounting practice and the discourse of ethics. Accounting, Organizations and Society 18 (2-3):231-252.

Shamir, R. 2004. The De-Radicalization of Corporate Social Responsibility. Critical Sociology 30 (3):669-689.

Sikka, P. 2011. Accounting for human rights: The challenge of globalization and foreign investment agreements. Critical Perspectives on Accounting 22 (8):811-827.

Sinclair, A. 1995. The chameleon of accountability: Forms and discourses. Accounting, Organizations and Society 20 (2-3):219-237.

Spence, C. 2007. Social and environmental reporting and hegemonic discourse. Accounting, Auditing \& Accountability Journal 20 (6):855-882.

- - 2009. Social accounting's emancipatory potential: A Gramscian critique. Critical Perspective on Accounting 20:205-227.

Spence, C., J. Husillos, and C. Correa-Ruiz. 2010. Cargo cult science and the death of politics: A critical review of social and environmental accounting research. Critical Perspective on Accounting 21:76-89.

Suleiman, A., and H. Mendras. 1995. Le recrutement des élites en Europe. Vol. La Decouverte. Paris.

Townley, B. 1995. 'Know Thyself': Self-awareness, Self-formation and Managing. Organization 2 (2):271-289.

- - 1 1996. Accounting in detail: accounting for individual performance. Critical Perspectives on Accounting 7 (5):565-584.

Unerman, J., and M. Bennett. 2004. Increased stakeholder dialogue and the internet: towards greater corporate accountability or reinforcing capitalist hegemony? Accounting, Organizations and Society 29:685-707.

Yunus, M., B. Moingeon, and L. Lehmann-Ortega. 2010. Building Social Business Models: Lessons from the Grameen Experience. Long Range Planning 43 (2-3):303-325.

Zizek, S. 1999. The Ticklish Subject. London: Verso. 


\section{Figure 1}

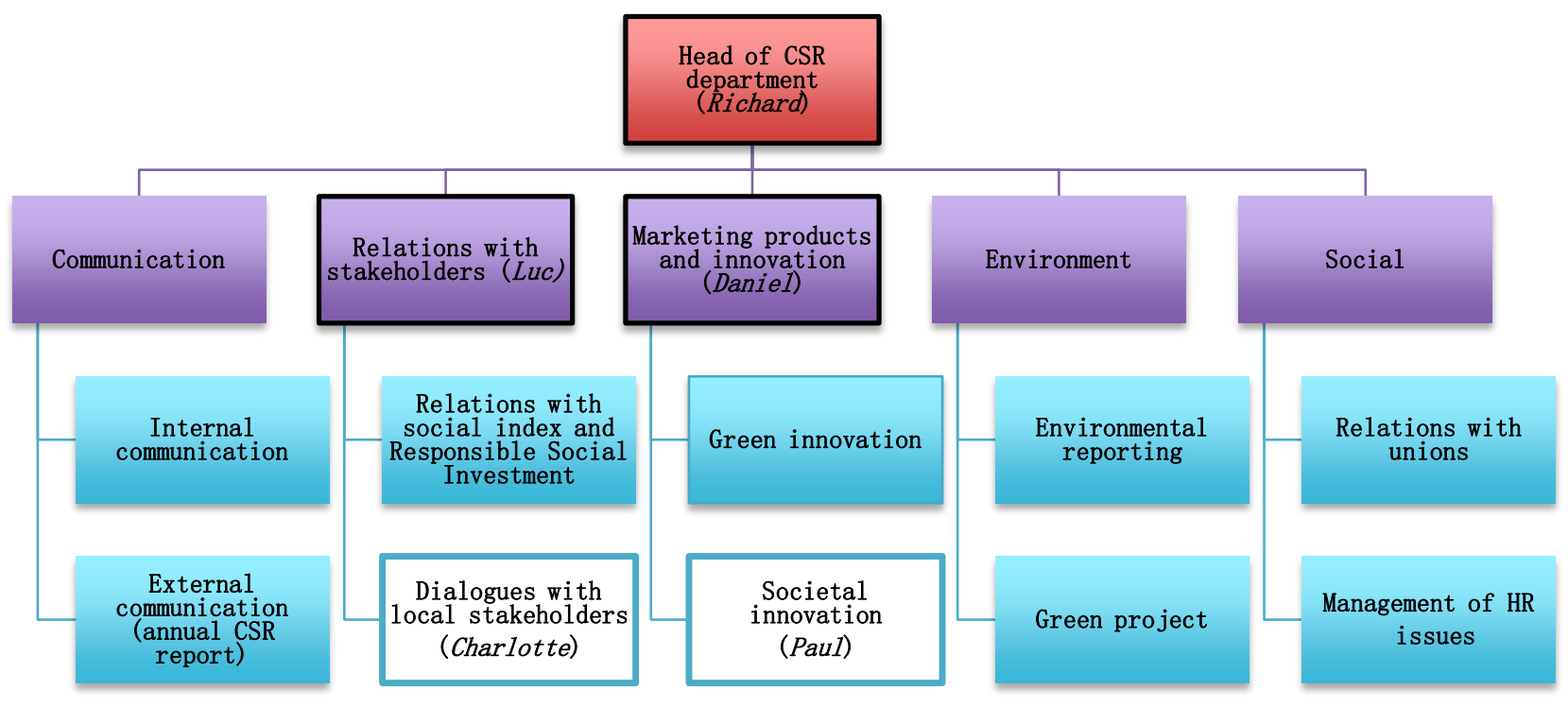

Organizational chart for the CSR department of Firm H 


\subsection{Figure 2}

\section{Telecoms solutions}

\begin{tabular}{|c|c|c|c|}
\hline Generic solutions & $\begin{array}{l}\text { Telecom associated } \\
\text { solutions }\end{array}$ & Issues resolved & Stake \\
\hline Farm training & $\begin{array}{l}\text { Specific terminal contains } \\
\text { voice portal }\end{array}$ & Improving farming & Productivity improvement \\
\hline Microcredit & Banking application & Purchase of inputs & Productivity improvement \\
\hline Saving & Banking application & $\begin{array}{l}\text { Purchase of tools and building } \\
\text { sites for storage }\end{array}$ & $\begin{array}{l}\text { Management improvement } \\
\text { Productivity improvement }\end{array}$ \\
\hline Irrigation system & $\begin{array}{l}\text { Remote management [by } \\
\text { phone] }\end{array}$ & Water management & Productivity improvement \\
\hline Weather info & Voice portal & Water management & Productivity improvement \\
\hline $\begin{array}{l}\text { Actors [e.g. merchants] } \\
\text { localisation }\end{array}$ & Geolocation of markets & $\begin{array}{l}\text { Localized merchants and } \\
\text { other actors to sell better }\end{array}$ & Sales Improvement \\
\hline Co-op & $\begin{array}{l}\text { Application gathering info on } \\
\text { groups }\end{array}$ & $\begin{array}{l}\text { Collective investment in tools } \\
\text { and storage sites }\end{array}$ & $\begin{array}{l}\text { Management improvement } \\
\text { Productivity improvement }\end{array}$ \\
\hline Market price information & $\begin{array}{l}\text { Application updating prices on } \\
\text { local market }\end{array}$ & $\begin{array}{l}\text { Better knowledge of market } \\
\text { prices to sell better }\end{array}$ & Sales Improvement \\
\hline
\end{tabular}

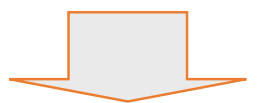

1. Productivity improvement

2. Management improvement

3. Sales Improvement

Source: PowerPoint presentation of the West African field trip - November 2011 - PowerPoint originally in French (translated by the authors). 


\subsection{Figure 3}

\section{The rural lab: what does it provide to stakeholders?}

Stakeholder contribution Stakeholder benefit

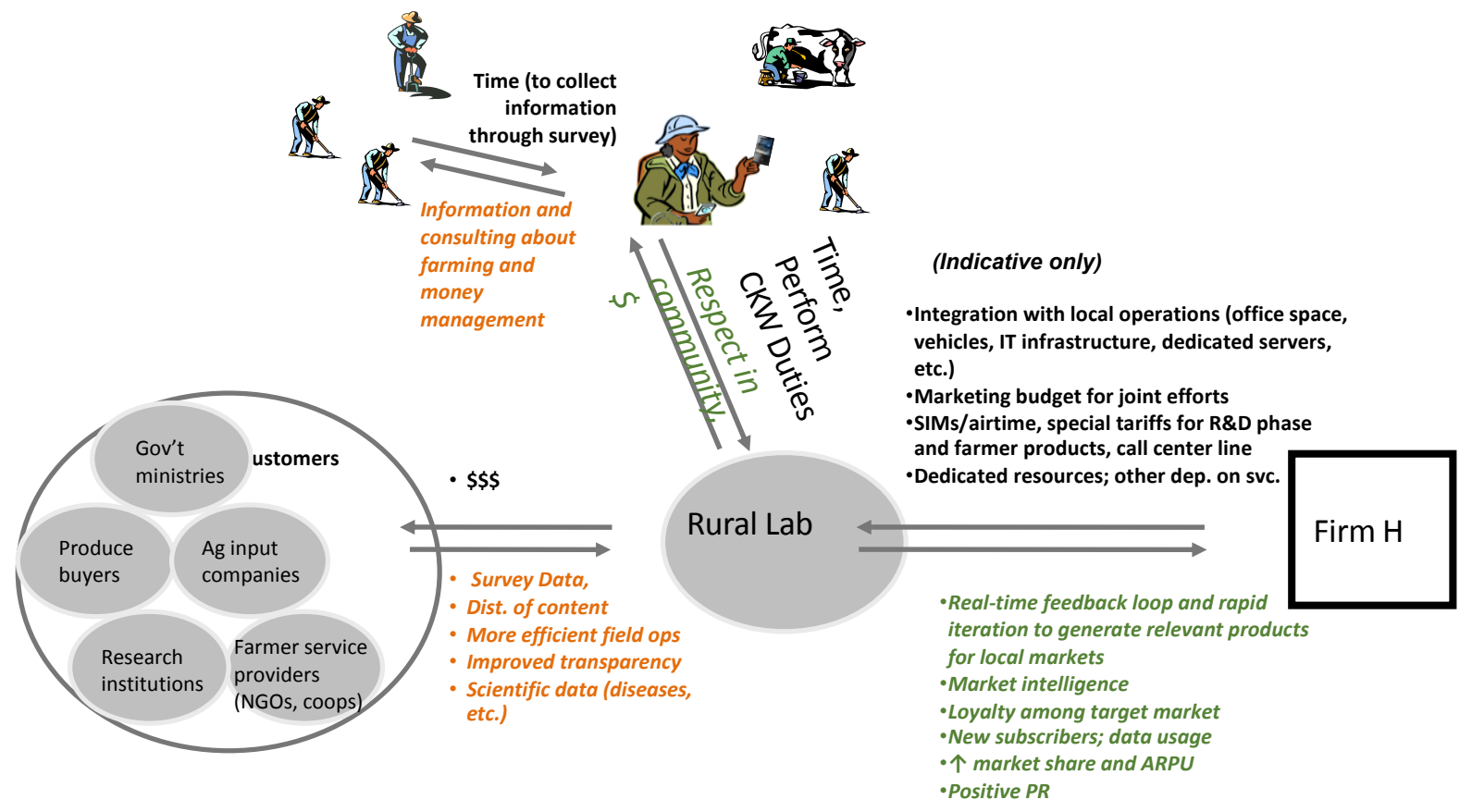

Source: PowerPoint presentation of the rural lab - March 2012 - PowerPoint originally in French (translated by the authors). 


\subsection{Figure 4}

\section{What is the business plan for the "rural lab"?}

-Long ROI (> 3years) but initial investment covered by backers

-Revenue from information collected on local populations sold to governments, international organizations, NGOs and major companies

- Project transfer to Firm $\mathrm{H}$ as soon as it is profitable

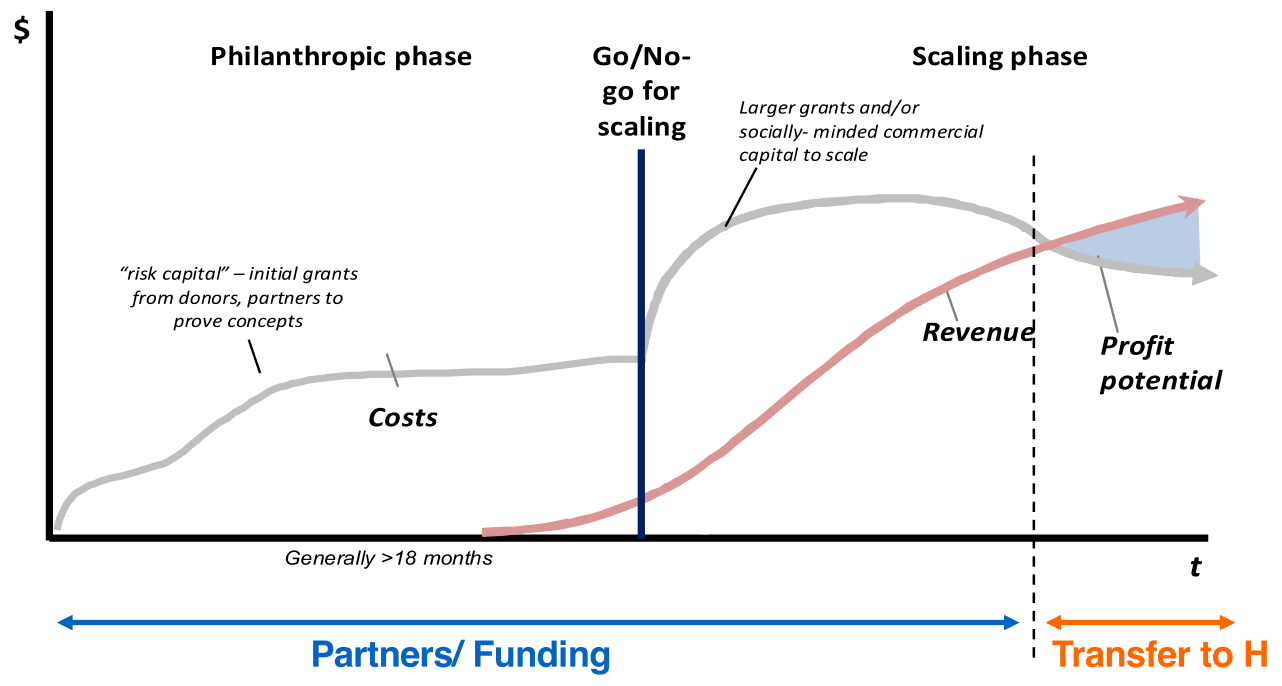

Source: PowerPoint presentation of the rural lab - Mars 2012 - PowerPoint originally in French, translated by the authors. 


\subsection{Figure 5}

- NB: roadmap covers three categories

- market animation: versions of existing products with current year revenue impact (ILM activity)

- mature innovations: products that could generate revenue in next 18 months

- new disruptive innovations: concepts that could generate revenue in $2 / 3$ years

8

Time to market information

Source: Screenshot extracted from PowerPoint presentation describing the product launch process March 2009 
Organizational chart for the CSR department of Firm H

\section{Table 1}

\begin{tabular}{|c|c|c|c|}
\hline \multicolumn{4}{|c|}{ One-to-one interviews } \\
\hline Name & Department & Position & Time \\
\hline Paul & Corporate CSR & In charge of societal innovation for marketing & $1: 49: 21$ \\
\hline Luc & Corporate CSR & Director of Stakeholder Relations & $1: 24: 56$ \\
\hline Daniel & Corporate CSR & Director of Marketing Products and Innovation & $1: 45: 40$ \\
\hline Richard & Corporate CSR & Head of CSR department & $1: 33: 48$ \\
\hline \multirow[t]{6}{*}{ Charlotte } & Corporate CSR & In charge of stakeholder dialogues & $1: 35: 25$ \\
\hline & Corporate CSR & Previous Head of CSR department & $2: 03: 26$ \\
\hline & $\begin{array}{l}\text { Quality for Africa and } \\
\text { the Middle East }\end{array}$ & |CSR Coordinator & $\mid \overline{51: 58}$ \\
\hline & $\begin{array}{l}\text { Quality for Africa and } \\
\text { the Middle East }\end{array}$ & $\begin{array}{l}\text { Director of Quality for Africa and the Middle } \\
\text { East }\end{array}$ & $55: 17$ \\
\hline & $\begin{array}{l}\text { Africa and Middle East } \\
\text { Department }\end{array}$ & & $1: 12: 45$ \\
\hline & \begin{tabular}{|l|} 
Africa and Middle East \\
Department
\end{tabular} & Head of the West Africa zone & $1: 15: 30$ \\
\hline \multirow[t]{4}{*}{ Jeanne } & \begin{tabular}{|l||} 
Marketing for Africa \\
and the Middle East
\end{tabular} & In charge of marketing reporting & $11: 23: 46$ \\
\hline & \begin{tabular}{|l|} 
Marketing for Africa \\
and the Middle East
\end{tabular} & Corporate Senior Marketer & $54: 10$ \\
\hline & \begin{tabular}{|l|} 
Marketing for Africa \\
and the Middle East
\end{tabular} & Corporate Junior Marketer & $1: 03: 00$ \\
\hline & COMEX & In charge of quality (including CSR) & $1: 20: 05$ \\
\hline \multicolumn{4}{|l|}{ Meetings } \\
\hline & \begin{tabular}{|l|} 
Marketing for Africa \\
and the Middle East
\end{tabular} & Director of Strategic Marketing & \multirow[t]{3}{*}{$1: 23: 46$} \\
\hline \multirow[t]{2}{*}{ Charlotte } & Corporate CSR & In charge of stakeholder dialogue & \\
\hline & $\begin{array}{l}\text { Marketing for Africa } \\
\text { and the Middle East }\end{array}$ & $\begin{array}{l}\text { In charge of marketing reporting and low-cost } \\
\text { products for rural populations }\end{array}$ & \\
\hline
\end{tabular}

